University of Florida Levin College of Law

UF Law Scholarship Repository

Summer 2014

\title{
Whole-System Agricultural Certification: Using Lessons Learned From Leed to Build a Resilient Agricultural System to Adapt to Climate Change
}

\author{
Mary Jane Angelo \\ University of Florida Levin College of Law, angelo@law.ufl.edu \\ Joanna Reilly-Brown
}

Follow this and additional works at: https://scholarship.law.ufl.edu/facultypub

Part of the Agriculture Law Commons, and the Environmental Law Commons

\begin{abstract}
Recommended Citation
Mary Jane Angelo \& Joanna Reilly-Brown, Whole-System Agricultural Certification: Using Lessons Learned From Leed to Build a Resilient Agricultural System to Adapt to Climate Change, 85 U. Colo. L. Rev. 689 (2014), available at http://scholarship.law.ufl.edu/facultypub/465
\end{abstract}

This Article is brought to you for free and open access by the Faculty Scholarship at UF Law Scholarship Repository. It has been accepted for inclusion in UF Law Faculty Publications by an authorized administrator of UF Law Scholarship Repository. For more information, please contact kaleita@law.ufl.edu. 


\title{
WHOLE-SYSTEM AGRICULTURAL CERTIFICATION: USING LESSONS LEARNED FROM LEED TO BUILD A RESILIENT AGRICULTURAL SYSTEM TO ADAPT TO CLIMATE CHANGE
}

\author{
MARY JANE ANGELO AND JOANNA REILLY-BROWN*
}

This Article proposes a novel approach to addressing global climate change's impacts on agricultural production and food security. The climate change crisis is the most significant environmental issue facing our planet. The changes predicted to occur as the earth's climate warms include significant impacts to agriculture. At the same time that the planet is undergoing dramatic climatic changes, the global population is increasing, and economic development in many parts of the world is exerting increased demand for a greater and more diverse supply of food.

The relationship between climate change and agriculture is a close and complex one, as the current system of agricultural production both contributes to, and will be impacted by, the effects of increased climate change phenomena. On the one hand, fossil fuel-intensive practices associated with the current industrialized agricultural system significantly contribute to the greenhouse gas (GHG) emissions considered to be the major cause of climate change. On the other, the predicted changes in global temperature and rainfall patterns associated with climate change have the potential to dramatically impact agricultural production. Changing weather conditions associated with climate change will likely impact agricultural production, affect food pricing, and reduce both global per capita calorie consumption and the nutritional value of some food, thereby increasing child malnutrition. Because of the close

\footnotetext{
* Mary Jane Angelo is a Professor of Law and Director of the Environmental and Land Use Law Program at the University of Florida Levin College of Law. Joanna Reilly-Brown holds a J.D. and Certificate in Environmental Law from the University of Florida Levin College of Law, a M.A. in Environmental Anthropology, and a B.A. in Anthropology from the University of Florida.
} 
relationship between climate change and agriculture, climate change has the potential to greatly impact global food security as its effects become more prevalent.

As the impacts of climate change on worldwide food production become more pronounced in the coming decades, it will become increasingly necessary to shift agricultural strategies away from current industrialized practices and toward a more resilient system of "ecologically-based" agriculture. This Article suggests that a key component to developing an agricultural system that can adapt to the likely impacts of climate change involves applying the concept of ecological resilience to increase agriculture's capacity to absorb climate change's impacts. Ecological resilience considers the magnitude of disturbance a system can absorb before the shock causes it to shift into another state. In an agricultural context, this concept describes a farm ecosystem's ability to adapt to shocks or disturbances, such as drought and pest and disease outbreaks, that threaten its ability to continue to function to produce acceptable crop yields.

In this Article, we suggest a new approach that we call "wholesystem" agriculture certification, which builds on the successes of eco-labeling and the United States organic certification program by rewarding ecologically-based practices that enhance an agricultural system's resilience in the face of climate changeinduced uncertainty. This Article proposes that this wholesystem agricultural certification approach be modeled after the successful Leadership in Energy \& Environmental Design (LEED) green building certification program, which certifies that buildings and communities are constructed according to specific standards designed to address aspects of environmental sustainability, and demonstrates how such a system would work.

INTRODUCTION 691

I. The AGRICUlture/Climate Change CYCLE.................698

A. Agriculture's Contribution to Climate Change .......699

B. Climate Change Impacts on Agriculture ..................700

C. Climate Change Impacts on Global Food Security.704

D. Strategies for Addressing Climate Change's Impacts to Agriculture: Mitigation and Adaptation 
1. Mitigation Strategies 709

2. Adaptation Strategies

II. LEARNING FROM ECO-AGRICULTURE: BIODIVERSITY, ECOSYSTEM SERVICES, AND THE COMPONENTS OF A RESILIENT AGRICULTURAL SYSTEM

A. Resilience through Biodiversity and the Provision of Ecosystem Services.

B. Industrial Agriculture: Non-Diverse and NonResilient

C. Eco-Agriculture: Enhancing Biodiversity and Ecosystem Services in Agricultural Systems.

III. EXISTING APPROACHES TO PROMOTING SUSTAINABLE AGRICULTURE: ECO-LABELING AND ORGANIC CERTIFICATION

A. Organic Labeling Programs

1. The United States Organic Food Production Act and National Organic Program ..................730

2. The European Union Organic Program ..............732

B. Other Eco-Labeling Efforts.....................................733

IV. LEED CERTIFICATION: WHOLE-BUILDING APPROACH ...736

V. FROM "WHOLE-BUILDING" TO "WHOLE-SYSTEM": USING LEED AS A MODEL FOR CERTIFYING AGRICULTURAL RESILIENCE

VI. PUTTING THE LEED APPROACH INTO PRACTICE ..............756

CONCLUSION .757

\section{INTRODUCTION}

The climate change crisis is without a doubt the most significant environmental issue facing our planet and its environment today. ${ }^{1}$ The changes predicted to occur as the earth's climate warms include significant impacts to

1. See generally NATIONAL RESEARCH COUNCIL OF THE NATIONAL ACADEMIES, AMERICA's Climate ChOICES (2011); INTERgovernmental PANEL on Climate Change, Special Report, Managing the Risks of Extreme EventS AND Disasters to ADVANCE Climate Change ADAPTATION (Christopher B. Field et al. eds., 2012), available at http://ipcc.ch/pdf/special-reports/ srex/SREX_Full_Report.pdf; Endangerment and Cause or Contribute Findings for Greenhouse Gases Under Section 202(a) of the Clean Air Act, 74 Fed. Reg. 66,496 (Dec. 15, 2009) [hereinafter Endangerment Finding]; Raymond B. Ludwiszewski \& Charles H. Haake, Climate Change: A Heat Wave of New Federal Regulation and Legislation, THE FED. LAWYER, June 2009, at 32 (explaining that global climate change is currently the most significant environmental concern). 
agriculture. ${ }^{2}$ At the same time that the planet is undergoing dramatic climatic changes, the global population is increasing, and economic development in many parts of the world is exerting increased demand for food. To ensure sufficient supply of food, agricultural systems must be rebuilt to be more resilient and, by extension, better able to adapt to climate change. This Article proposes a mechanism for achieving resilient agricultural systems through the use of whole-system certification modeled after the Leadership in Energy \& Environmental Design (LEED) green building certification program.

Global climate change is now a generally accepted reality within the scientific community and the general public, as a growing body of research has persuasively demonstrated the link between human-induced factors, such as increased carbon emissions, and the continued generation of significant increases in global atmospheric temperatures. ${ }^{3}$ The results of this research have led scientists to predict that, without substantial reductions in the amount of carbon released into the earth's atmosphere, the expected increase in global temperature will produce significant climatic changes that will lead to a host of environmental harms, including continued warming, ${ }^{4}$ sea level rise, ${ }^{5}$ salt water intrusion, ${ }^{6}$ increased precipitation and flooding in some areas, ${ }^{7}$ increased incidence

2. U.S. ENVTL. PRot. AGency, Climate Impacts on Agriculture and Food Supply, http://www.epa.gov/climatechange/impacts-adaptation/agriculture.html (last visited Oct. 15, 2013).

3. See, e.g., Intergovernmental Panel On Climate Change, Climate Change 2007: SYNTHESIS REPORT, SUMMARY FOR POLICYMAKERS 1, 10 (Larry Bernstein et al. eds., 2008) [hereinafter IPCC SUMMARY FOR POLICYMAKERs], available at http://www.ipcc.ch/pdf/assessment-report/ar4/syr/ar4_syr_spm.pdf. (stating that most of the recorded increase in global temperatures is very likely attributable to human-induced increases in GHG concentrations); Endangerment Finding, supra note 1.

4. The Intergovernmental Panel on Climate Change (IPCC) Report states that it is "[v]irtually certain" ( $>99$ percent probability of occurrence) that future warming will occur. INTERgovernMENTAL PANEL ON CLIMATE CHANGE, Climate CHANGE 2007: SYNTHESIS REPORT 53 (Larry Bernstein et al. eds., 2008) [hereinafter IPCC 2007], available at http://www.ipcc.ch/pdf/assessmentreport/ar4/syr/ar4_syr.pdf. For an explanation of the probability terminology used in the IPCC report, see id. at 27.

5. According to the IPCC Report, it is "[1]ikely" ( $>66$ percent probability of occurrence) that there will be increased incidents of high sea level. Id at 53.

6. According to the IPCC Report, saltwater intrusion is one of the major projected impacts of increased incidents of high sea level. Id.

7. According to the IPCC Report, it is "[v]ery likely" (>90 percent probability 
of drought in many geographic locales, ${ }^{8}$ increased frequency of heat waves, ${ }^{9}$ and more intense severe weather events. ${ }^{10}$ As the earth warms, the effects of climate change are expected to compound with other environmental and natural resource concerns, such as deforestation and pollution, ${ }^{11}$ causing significant changes in aquatic, terrestrial, and hydrological systems across the globe that will most certainly impact human populations' food security, health, and environmental stability.

Agriculture is one system that stands to be significantly impacted by global climate change. The relationship between climate change and agriculture is a close and complex one, as the current system of agricultural production both contributes to, and will be impacted by, the effects of increased climate change phenomena. ${ }^{12}$ On the one hand, fossil fuel-intensive practices associated with the current industrialized agricultural system significantly contribute to the greenhouse gas (GHG) emissions considered to be the major cause of climate change. ${ }^{13}$ Agriculture currently accounts for approximately 20 percent of fossil fuel usage in the United States, as industrialized farming practices such as pesticide development and application, plowing and harvesting, and processing and transportation of farm products rely heavily on the use of fossil fuels. ${ }^{14}$ In addition, industrial agricultural practices, such as concentrated animal feeding operations,

of occurrence) that there will be increased heavy precipitation in some areas of the globe. $I d$.

8. According to the IPCC Report, it is "[1]ikely" ( $>66$ percent probability of occurrence) that there will be an increased number of droughts. Id.

9. According to the IPCC Report, it is "[v]ery likely" ( $>90$ percent probability of occurrence) that there will be an increased number of heat waves. Id.

10. According to the IPCC Report, it is "[1]ikely" ( $>66$ percent probability of occurrence) that there will be more intense tropical cyclone events. Id.

11. Id. at 70 .

12. Mary Jane Angelo, Corn, Carbon, and Conservation: Rethinking U.S. Agricultural Policy in a Changing Global Environment, 17 GEO. MASON L. REV. 593, 599-600 (2010).

13. William S. Eubanks II, A Rotten System: Subsidizing Environmental Degradation and Poor Public Health with Our Nation's Tax Dollars, 28 STAN. ENVTL. L.J. 213, 269-70 (2009). See also Angelo, supra note 12, at 612-13.

14. See Eubanks, A Rotten System, supra note 13, at 269-70; see also Jason J. Czarnezki \& Elisa K. Prescott, Environmental and Climate Impacts of Food Production, Processing, Packaging, and Distribution, in FOOD, AGRICULTURE, AND Environmental LAW 113, 117-20 (Mary Jane Angelo, Jason J. Czarnezki \& William S. Eubanks II eds., 2013); Peter Warshall, Tilth and Technology: The Industrial Redesign of Our Nation's Soils, in FATAL HARVEST: THE TRAGEDY OF INDUSTRIAL AGRICULTURE 221, 225 (Andrew Kimbrell ed., 2002). 
continue to release substantial amounts of methane, a greenhouse gas significantly more powerful than carbon dioxide, ${ }^{15}$ into the earth's atmosphere. ${ }^{16}$

On the other hand, the predicted changes in global temperature and rainfall patterns associated with climate change have the potential to dramatically impact agricultural production. ${ }^{17}$ Research evaluating the probable impacts of climate change on agricultural production predicts that the severity of impacts over the coming century will depend largely on geographic location and the unique production aspects of existing regional agricultural systems. ${ }^{18}$ Despite these differing regional effects, the changing weather conditions associated with climate change will likely impact, to varying degrees, agricultural production and food pricing, and reduce both global per capita calorie consumption and the nutritional value of some food, thereby increasing child malnutrition. ${ }^{19}$ Because of the close relationship between climate change and agriculture, climate change has the potential to greatly impact global food security as its effects become more prevalent.

In response to the growing recognition of the complicated relationship between climate change and worldwide agricultural production, many scientists, farmers, environmentalists, and policymakers have begun to advocate replacing industrialized agriculture with less fossil fuelintensive and more sustainable approaches to agricultural production. ${ }^{20}$ This Article goes a step further, suggesting that a

15. Annise Maguire, Shifting the Paradigm: Broadening our Understanding of Agriculture and its Impact on Climate Change, 33 ENVIRONS ENVTL. L. \& POL'Y 275,286 (2010). The "power" of a greenhouse gas is measured using its Global Warming Potential (GWP), which compares the total warming effect of the gas, over a specified period of time, to the warming effect of carbon dioxide. The GWP of one ton of methane is equal to twenty to thirty tons of carbon dioxide. Id.

16. See generally Hannah M.M. Connor, The Industrialization of Animal Agriculture: Connecting a Model With Its Impacts on the Environment, in FOOD, AGRICULTURE, AND ENVIRONMENTAL LAW 65 (Mary Jane Angelo, Jason J. Czarnezki \& William S. Eubanks II eds., 2013).

17. Susan Charles, Climate Change: Impacts On Food Safety, NAT. RESOURCES \& ENV'T, Summer 2011, at 44, 44.

18. Id.

19. Gerald C. Nelson et al., INT’’ Food Policy Research inst., Climate CHANGE: IMPACT ON AGRICULTURE AND COSTS OF ADAPTATION 4-12 (2009), available at $\mathrm{http} / / / \mathrm{www}$.ifpri.org/sites/default/files/publications/pr21.pdf.

20. See The Nairobi Declaration, ECOAGRICULTURE PARTNERS (Oct. 1, 2004), http://www.ecoagriculture.org/documents/nairobi/Nairobi_Declaration_english.pdf (joint statement by participants of 2004 International Ecoagriculture Conference 
key component to developing an agricultural system that can adapt to the likely impacts of climate change involves applying the concept of ecological resilience to increase agriculture's capacity to absorb climate change's impacts. Ecological resilience considers the magnitude of disturbance a system can absorb before the shock causes it to shift into another state. ${ }^{21}$ In an agricultural context, this concept, which this Article refers to as "agricultural resilience," describes a farm ecosystem's ability to adapt to shocks or disturbances, such as drought and pest and disease outbreaks, that threaten its ability to continue to function to produce acceptable crop yields. ${ }^{22}$ Although much has been written in the past several years about the benefits of sustainable agriculture, very little attention has been paid to finding ways to build resilient agricultural systems that will be better able to absorb the effects of, and adapt to, climate change. ${ }^{23}$

The impacts of climate change on worldwide food production will become more pronounced in the coming decades. ${ }^{24}$ It will therefore become increasingly necessary to shift agricultural strategies away from current industrialized practices toward a more resilient system of agricultural production. The challenge is to develop a method to promote agricultural resilience that will cause a substantial shift in attitudes and practices on the massive scale necessary to effectively transform the system.

A number of approaches have been attempted or suggested to address discrete concerns regarding the health and environmental impacts of agriculture, including climate change

and Practitioner's Fair); see also JefFrey A. MCNeEly \& SARA J. SCHERR, ECOAGRICULTURE: STRATEGIES TO FEED THE WORLD AND SAVE BIODIVERSITY 93 (2003). See generally JUDITH D. SOULE \& JON K. PIPER, FARMING IN NATURE'S IMAGE: AN ECOLOGICAL APPROACH TO AGRICULTURE (1992); Sara J. Scherr \& Jeffrey A. McNeely, The Challenge for Ecoagriculture, in FARMING WITH NATURE: THE SCIENCE AND PRACTICE OF ECOAGRICULTURE 1, 2-6 (Sara J. Scherr \& Jeffrey A. McNeely eds., 2007).

21. Lance H. Gunderson et al., Resilience of Large-Scale Resource Systems, in RESILIENCE AND THE BEHAVIOR OF LARGE-SCALE SYSTEMS 3, 4 (Lance H. Gunderson \& Lowell Pritchard Jr. eds., 2002).

22. Ika Darnhofer et al., Assessing a Farm's Sustainability: Insights from Resilience Thinking, 8 INT'L J. AGRIC. SUSTAINABILITY 186, 187 (2010).

23. Id. at $186-87$.

24. Anthony Costello et al., Global Health and Climate Change: Moving from Denial and Catastrophic Fatalism to Positive Action, 369 PHIL. Transactions ROYAL SOC'Y A 1866, 1874 (2011). 
impacts. Proposed approaches include capitalizing on consumer preferences for foods grown in environmentally friendly ways through product labeling (sometimes referred to as "ecolabeling") and promoting farming practices modeled on natural ecosystems (referred to as "eco-agriculture"). Eco-labeling seeks to promote agricultural sustainability through the use of product labels that evaluate the ecological and carbon footprint of agricultural products. ${ }^{25}$ The United States' organic agriculture certification program, for example, relies on a type of eco-label, an "organic" label, which certifies that products carrying the label were produced without the use of synthetic pesticides and other synthetic substances. ${ }^{26}$ However, as described in more detail in this Article, a major weakness of most existing eco-labeling systems involves their explicit focus on environmental issues associated with discrete aspects of production (i.e., prohibitions on the use of synthetic fertilizer and pesticides) and consequent failure to address the overall resilience of the agricultural system.

Another much-discussed concept, eco-agriculture, applies an ecosystem approach to agricultural production by promoting agricultural sustainability through the use of farming practices that employ the concept of the farm as a healthy sustainable living system, not an industrial production facility. ${ }^{27}$ Ecoagriculture practices increase the ecological resilience of an agricultural system by maintaining biodiversity and ecosystem service provision, which are described in more detail in Part II of this Article. This increase in resilience enhances the health and function of all components of the farm ecosystem, including aspects related to the maintenance of fertile soils; management of populations of natural predators, pollinators, and parasites; and promotion of biodiversity. ${ }^{28}$

In this Article, we suggest a new approach, which we call "whole-system" agriculture certification. This approach integrates the concept of eco-agriculture with the practice of eco-labeling to achieve the goal of increasing resilience in

25. Jason J. Czarnezki, The Future of Eco-Labeling: Organic, Carbon Footprint, and Environmental Life-Cycle Analysis, 30 STAN. ENVTL. L.J. 3, 5 (2011).

26. Id. at 6 .

27. MCNEELY \& SChERR, ECOAGRICULTURE: STRATEGIES, supra note 20, at 93.

28. See id. at 109. 
agricultural systems. The whole-system agriculture certification approach builds on the successes of eco-labeling and the United States' organic certification program, while integrating ecologically based practices designed to enhance an agricultural system's resilience in the face of climate changeinduced uncertainty. This Article models this whole-system agricultural certification approach after the successful LEED green building certification program, which certifies that buildings and communities are constructed according to specific standards designed to address aspects of environmental sustainability. ${ }^{29}$ LEED is designed to address the entire lifecycle of a building, including its design, construction, and operation, thus employing a whole-building approach to certifying green buildings. ${ }^{30}$ Under LEED, a project earns points for achievement across major credit categories that address discrete aspects of a building's overall sustainability. ${ }^{31}$ The widely respected program has been praised as an innovative and effective approach to green building certification. ${ }^{32}$ LEED could provide the basis for designing a similar "whole-system" agricultural certification

29. LEED, U.S. GREEN BLDG. CoUNCIL, http://www.usgbc.org/leed (last visited Dec. 5, 2013). This Article is the first to propose a "whole-system" agricultural certification program modeled after the LEED program. In an article in Scientific American, author Jonathan A. Foley briefly mentioned a related idea of using a LEED-type approach to award points to foods based on "how well they deliver nutrition, food security and other public benefits, minus their environmental and social costs." Jonathan A. Foley, Can We Feed the World \& Sustain the Planet?, SCI. AM., Nov. 2011, at 60, 65. Foley's proposal, however, does not address the "whole-system" approach geared toward building a resilient agricultural system to adapt to climate change. Nor does it set forth details on how the point system would operate.

30. About LEED, U.S. GREEN BLDG. CoUNCIL, http://www.usgbc.org/articles/ about-leed (last visited Dec. 5, 2013).

31. LEED Rating Systems, U.S. GREEN BLDG. COUNCIL, https://usgbc.org/leed/ rating-systems (last visited Mar. 20, 2014).

32. See Darren A. Prum, Creating State Incentives for Commercial Green Buildings: Did the Nevada Experience Set an Example or Alter the Approach of Other Jurisdictions?, 34 WM. \& MARY ENVTL. L. \& POL'Y REV. 171, 172 n.5 (2009); Ashley Muse \& Josette M. Plaut, An Inside Look at LEED: Experienced Practitioners Reveal the Inner Workings of LEED, J. GREEN BUILDING, Winter 2006, at 3; Elissa Black, Green Neighborhood Standards from a Planning Perspective: The LEED for Neighborhood Development (LEED-ND), 5 FocUs: J. City \& Regional Planning DeP'T 41, 42 (2008); Stephen T. Del Percio, Skyscraper, Green Design, \& the LEED Green Building Rating System: The Creation of Uniform Sustainable Standards for the 21st Century or the Perpetuation of an Architectural Fiction?, 28 ENVIRONS ENVTL. L. \& POL'Y J. 117, 120 (2004). 
program, modeled after LEED's "whole-building" certification, wherein points would be awarded to farms implementing sustainable practices across specified categories that capture the components of agricultural resilience.

The concepts of agricultural resilience and eco-agriculture have gained acceptance and popularity in recent years. What is lacking is a concrete approach to put these concepts into widespread practice. This Article argues that LEED can provide some insight into how a whole-system agricultural certification program could be designed and implemented. Part I of the Article reviews climate change's predicted impacts to agriculture and discusses the major strategies being proposed to minimize or adapt to these changes. Part II investigates the different components of a resilient agricultural system, using the concepts of biodiversity, ecosystem services, and ecoagriculture to gain a better understanding of the components necessary for an agricultural system to resiliently absorb shocks or disturbances. Part III provides a discussion of the strengths and weaknesses of existing eco-labeling and organic certification programs designed to address aspects of agricultural sustainability. Part IV describes the LEED green building certification program, focusing on the certification process and credit categories for which points are awarded. Part V proposes a new whole-system approach to agricultural sustainability certification that builds on the design of the LEED program by incorporating principles of agricultural resilience from eco-agriculture.

\section{The Agriculture/Climate Change Cycle}

Climate change and agriculture are tightly linked in a number of ways. On the one hand, the existing modern agricultural system is a significant contributor to GHG emissions, which are linked to climate change. ${ }^{33}$ On the other hand, changes in temperature and rainfall patterns that are likely to occur as a result of climate change could significantly

33. P. Smith, et al., Agriculture, 499, 503-05 in INTERGovernMENTAL PANEL on Climate Change, Climate Change 2007: Mitigation of Climate Change, CONTRIBUTION OF WORKING GROUP III TO THE FOURTH ASSESSMENT REPORT OF THE IPCC (B. Metz, et al. eds., 2007), available at http://www.ipcc.ch/pdf/ assessment-report/ar4/wg3/ar4_wg3_full_report.pdf. 
impact global food production. ${ }^{34}$ In this Part, we review the complicated relationship between climate change and agriculture by first discussing the ways in which agriculture contributes to climate change. We then analyze the ways in which climate change is predicted to impact both agricultural production and global food security. This Part concludes with a discussion of the major strategies being proposed to both minimize agriculture's contribution to climate change and adapt agriculture to the likely impacts of climate change.

\section{A. Agriculture's Contribution to Climate Change}

Agriculture contributes to climate change in a variety of ways, with heavy use of fossil fuels and consequent high GHG emissions being perhaps the most significant. The high-yield, industrialized agricultural practices used in the United States and in most of the developed world rely heavily on fossil fuel inputs, thus creating a large "carbon footprint." Most pesticides and fertilizers used in industrial agriculture are made from fossil fuels. ${ }^{35}$ Heavy machinery, such as tractors, combines, and trucks that farms use to transport agricultural products to processing facilities and ultimately to retailers, uses significant amounts of gasoline and diesel fuel. ${ }^{36}$ Agriculture accounts for approximately 20 percent of the United States' fossil fuel consumption. ${ }^{37}$ Globally, agriculture is believed to comprise approximately 15 percent of GHG emissions, ${ }^{38}$ and the Environmental Protection Agency (EPA) estimates that approximately 8 percent of the United States' GHG emissions can be attributed to agriculture. ${ }^{39}$ It takes "10 calories of petroleum to yield just one calorie of industrial food" and about two-thirds of a gallon of gasoline to produce one bushel of

34. Eubanks, A Rotten System, supra note 13, at 269-70.

35. Warshall, supra note 14 , at 225.

36. Czarnezki \& Prescott, supra note 14, at 117-18; William S. Eubanks II, The Sustainable Farm Bill: A Proposal for Permanent Environmental Change, 39 ENVTL. L. REP. 10493, 10504 (2009), available at http://elr.info/ news-analysis/39/10493/sustainable-farm-bill-proposal-permanent-environmentalchange; Warshall, supra note 14, at 225.

37. Eubanks, $A$ Rotten System, supra note 13, at 269 (citing DANIEL IMHOFF, Food FIGHT: THE CITIZEN's GUIDE TO A FOOD AND FARM BILL 102 (1st ed. 2007)).

38. Eubanks, The Sustainable Farm Bill, supra note 36, at 10504.

39. Sources of Greenhouse Gas Emissions, U.S. ENVTL. PROT. AGENCY, http://www.epa.gov/climatechange/ghgemissions/sources.html (last visited Aug. 6, 2013). 
industrial corn. ${ }^{40}$

One of the most significant GHG emissions associated with industrialized agricultural production is methane gas released from animal operations. ${ }^{41}$ Livestock, such as cows, that are kept in confined feeding operations and are fed large quantities of corn and other grains, emit substantial amounts of methane gas. ${ }^{42}$ Methane gas is approximately twenty times more powerful a GHG than carbon dioxide. ${ }^{43}$ Though methane gas is a natural animal waste product, the enormous amount of methane gas produced in industrial animal production is a direct result of the huge numbers of animals housed in confined feeding operations. ${ }^{44}$

\section{B. Climate Change Impacts on Agriculture}

While industrial agriculture is certainly a significant contributor to climate change, it is also simultaneously extremely vulnerable to the likely impacts of climate change. In fact, our global system of agricultural production as a whole is very vulnerable to the widespread ecosystem changes that will almost certainly accompany climate change. ${ }^{45}$ This vulnerability has the potential to greatly impact the volume and quality of global and regional food production, thereby potentially reducing global food security. ${ }^{46}$ Climate change will produce a suite of environmental changes that will force

40. Eubanks, The Sustainable Farm Bill, supra note 36, at 10504 (citing

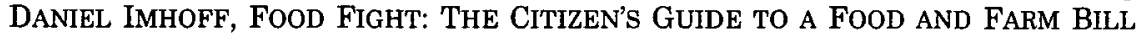
102 (1st ed. 2007)).

41. Joshua A. Utt et al., Carbon Emissions, Carbon Sinks, and Global Warming, in AGRICULTURAL POLICY AND THE ENVIRONMENT 151, 156 (Rodger E. Meiners \& Bruce Yandle eds., 2003).

42. Eubanks, The Sustainable Farm Bill, supra note 36, at 10504.

43. Id.

44. See id.

45. Miguel F. Acevedo, Interdisciplinary Progress in Food Production, Food Security and Environmental Research, 38 ENVTL. CONSERVATION 151, 156 (2011).

46. The United Nations Food and Agriculture Organization (FAO) defines "food security" as existing when "all people at all times have physical or economic access to sufficient safe and nutritious food to meet their dietary needs and food preferences for an active and healthy life." INTERDEPARTMENTAL WORKING GROUP on Climate Change, U.N. Food and Agric. ORg., Climate Change AND FOOD SECURITY: A FRAMEWORK DOCUMENT at 3 (2008) [hereinafter FAO FOOD SECURITY], available at http://www.fao.org/forestry/15538. 079b31d45081fe9c3dbc6ff34de4807e4.pdf. The FAO definition encompasses four dimensions: food availability, food accessibility, food utilization, and food systems stability. Id. 
agricultural systems around the world to absorb or adapt. These changes include modifications to water availability, ${ }^{47}$ mean precipitation, ${ }^{48}$ seasonality, ${ }^{49}$ and the emergence of new diseases and pests. ${ }^{50}$ Each of these predicted changes will likely become stronger as they interact with each other and as global mean temperatures continue to increase. 51

The ultimate concern regarding the effects of climate change on agriculture is the extent to which these effects negatively alter crop yield, which in turn affects food prices and food security. Crop yields can be affected by a number of expected climate change impacts, including changes in precipitation, temperature, sea level, carbon dioxide levels, and disease and pest outbreaks. ${ }^{52}$

One of the greatest threats climate change poses to agriculture involves its predicted impacts on water availability across different regions of the globe. The altered rainfall patterns expected to result from climate change will most likely increase droughts in some areas and increase flooding in others. ${ }^{53}$ Climate change is expected to severely exacerbate water scarcity in many already water-stressed areas, as current projections point to the potential for significant drying in many areas of the world in which water availability is already an issue. ${ }^{54}$ This predicted scarcity will likely be exacerbated in many areas by the increased temperatures and changing seasonality of precipitation patterns associated with climate change. ${ }^{55}$ Agricultural systems will therefore be forced to compete for already scarce water resources in the face of warmer temperatures and increased uncertainty. Changed rainfall patterns and increased temperatures are projected to

47. William Easterling et al., Food, Fibre and Forest Products, in intergovernmental Panel on Climate Change, Climate Change 2007: IMPACTS, ADAPTATION AND VULNERABILITY, CONTRIBUTION OF WORKING GROUP II TO THE FOURTH ASSESSMENT REPORT OF THE INTERGOVERNMENTAL PANEL ON Climate Change 273, 298 (Martin Parry et al. eds., 2007), available at http://www.ipcc.ch/pdf/assessment-report/ar4/wg2/ar4-wg2-chapter5.pdf.

48. IPCC 2007 , supra note 4 , at 46 .

49. Id. at 48 .

50. Easterling et al., supra note 47 , at 298.

51. ANITA Wreford ET AL., ORG. FOR ECON. COOPERATION \& Dev. Climate CHANGE AND AGRICULTURE: IMPACTS, ADAPTATION AND MITIGATION 22 (2010).

52. See generally Charles, supra note 17 , at 44.

53. WREFORD ET AL., supra note 51, at 22.

54. Id.

55. Id. at 21 . 
produce decreased crop yields and increased incidence of weeds and pests in many areas, particularly in developing regions, which stand to experience the impacts of climate change most profoundly. .56

The extent to which the effects of climate change will reduce global crop yields is perhaps the most significant concern regarding the future impacts of climate change on agriculture. ${ }^{57}$ The rising temperatures and changes in precipitation patterns associated with climate change will directly affect crop yields, particularly in developing countries. ${ }^{58}$ Climate models predict declines in yield for most crops in developing countries, with irrigated wheat and rice experiencing the most significant declines. ${ }^{59}$ South Asia is the region predicted to experience the greatest declines in yield, particularly for rain-fed maize and wheat crops. ${ }^{60} \mathrm{Sub}$-Saharan Africa likely will experience significant declines in rain-fed wheat yields and small declines or increases in maize yields.61 Latin America and the Caribbean will likely experience mixed effects to crop yields, with some crop yields increasing and others decreasing. ${ }^{62}$ The developed world likely will not experience impacts as dramatic overall, but some geographic areas could experience significant adverse effects, and the overall nutritional value of the food grown could be impacted. ${ }^{63}$

Even in wealthier countries, however, climate change has the potential to significantly impact agriculture by altering growing seasons and changing the types of crops and crop varieties that can be grown in particular regions. The United States Global Change Research Program predicts decreased yields for many crops in the United States, including corn, rice, and sorghum. ${ }^{64}$ Several factors contribute to the likely

56. NELSON ET AL., supra note 19 , at 4 .

57. See WREFORD ET AL., supra note 51, at 40.

58. NELSON ET AL., supra note 19 , at 4.

59. Id.

60. Id.

61. Id.

62. Id.

63. U.S. Global Change Research Program, Global Climate Change IMPACTS IN THE UNITED STATES 71 (Thomas R. Karl et al. eds., 2009) [hereinafter USGCRP, IMPACT REPORT], available at http://downloads.globalchange. gov/usimpacts/pdfs/climate-impacts-report.pdf. While plants generally grow larger with increased carbon dioxide levels, some crops show reduced nitrogen and protein content and are therefore less nutritious. Id. at 73.

64. Id. at 72 . 
decreases. ${ }^{65}$ Longer growing seasons resulting from increased temperatures will occur at the same time that less water is available due to increased drought in many regions. ${ }^{66}$ As the climate warms, weeds, pest insects, and diseases are likely to increase as conditions become more hospitable for new pests and diseases to move into areas that were previously inhospitable due to cold temperatures. ${ }^{67}$ Moreover, some studies show that growing certain crops in higher carbon dioxide environments can lead to significant increases in pest damage. ${ }^{68}$ Studies indicate that some widely used weed control chemicals, such as glyphosate, will lose their efficacy in an environment with elevated carbon dioxide. ${ }^{69}$ Finally, sea level rise and the resulting saltwater intrusion in some coastal regions might take land out of agricultural production..$^{70}$

Despite the predicted decreases in yield for several major crops in the United States, studies also somewhat counterintuitively suggest that elevated levels of carbon dioxide associated with climate change could actually facilitate yield increases for some major crops in the developed world. ${ }^{71}$ These predicted higher yields, however, will likely be tempered somewhat by complicated interactions with other effects of climate change, such as increased prevalence of pests, decreased resource availability, and increased incidence of extreme weather events. ${ }^{72}$ Whether the predicted positive impacts of elevated carbon dioxide to crop yields actually occur also will depend on limiting factors, such as availability of water, nutrients, and other parameters of biological productivity within the system. ${ }^{73}$ As such, it is likely that climate change impacts on crop yields will depend heavily on factors such as geographic location and rate of precipitation. ${ }^{74}$

The effect of changing weather conditions on agriculture

65. Simon N. Gosling et al., A Review of Recent Developments in Climate Change Science. Part II: The Global-Scale Impacts of Climate Change, 35 PROGRESS IN PHYSICAL GEOGRAPHY 443, 451-53 (2011).

66. USGCRP, IMPACT REPORT, supra note 63, at 72-73.

67. Id. at 75 .

68. Id. at 76 .

69. Id. at 75 .

70. FAO FOOD SECURITY, supra note 46 , at 28.

71. WREFORD ET AL., supra note 51, at 24.

72. Id.

73. Id.

74. Id. at 27 . 
will impact food production and pricing, which in turn will affect individual farmers' abilities to meet the food and health needs of their families and communities. ${ }^{75}$ Studies investigating the likely effects of climate change on food prices suggest that, on average, food prices for all major crops (rice, maize, wheat, and soybeans) will rise moderately until 2050 , along with the projected moderate increases in temperature projected for the same time period. ${ }^{76}$ After 2050, however, temperatures are expected to increase at a higher rate, and global food prices are consequently expected to rise substantially with this rapid increase in warming. ${ }^{77}$

Research that evaluates probable impacts of climate change on agriculture over the coming century largely indicates that climate change will produce both positive and negative impacts, depending on geographic location and regional variation in agricultural systems. ${ }^{78}$ There is considerable uncertainty about the extent to which crop yields are likely to increase or decrease in a warming climate, and general trends are difficult to predict. ${ }^{79}$ Nevertheless, most scientists agree that the most dramatic changes in precipitation and temperature are likely to occur in the world's poorest and most vulnerable regions in the developing world, ${ }^{80}$ resulting in disproportionate impacts on food security in these areas.

\section{Climate Change Impacts on Global Food Security}

As the predicted effects of climate change become more prevalent over the coming century, it is highly likely that global food security will be increasingly difficult to maintain as agricultural systems worldwide begin to experience impacts to water availability, changes in crop yield, and changes in prices. The United Nations Food and Agriculture Organization defines "food security" as existing when "all people at all times have physical or economic access to sufficient safe and nutritious food to meet their dietary needs and food preferences for an

75. See id. at 50.

76. NELSON ET AL., supra note 19 , at 8.

77. WREFORD ET AL., supra note 51 , at 50.

78. Thomas W. Hertel \& Stephanie D. Rosch, Climate Change, Agriculture, and Poverty, 32 APPLIED ECON. PERSP. \& POL'Y 355, 358 (2010).

79. WREFORD ET AL., supra note 51, at 37 .

80. Charles, supra note 17 , at 44. 
active and healthy life." 81 Included within this definition are four dimensions: (1) food availability, (2) food accessibility, (3) food utilization, and (4) food systems stability. ${ }^{82}$ Climate change will affect the ability of global food systems to achieve each of these four dimensions. ${ }^{83}$ The impacts of climate change on each of these dimensions are discussed in more detail below.

Because research suggests that the world's poorest and most vulnerable regions will experience the most significant climate change-induced impacts, food security in these developing areas of the world will likely be more threatened by the effects of climate change than food security in wealthier areas. ${ }^{84}$ Nevertheless, climate change will certainly affect food security in the developed world, albeit in different ways. ${ }^{85}$ Indeed, the disproportionate impacts of climate change on the livelihoods and food security of the poor will present significant challenges as we struggle to meet the ever-increasing global population's demands for food and resources in coming years.

The effect of changing weather patterns on the volume and quality of global and regional food production stands to greatly impact food availability for many already vulnerable global populations. ${ }^{86}$ For example, availability of food in Africa will likely be "severely compromised" by variability in climate conditions. ${ }^{87}$ Modified climate conditions will likely reduce the length of growing seasons and force some areas out of agricultural production. 88 This could exacerbate current waterstress and scarcity issues in many semi-arid regions of Africa. These shorter growing seasons and decreased areas devoted to agricultural production will translate to less food production overall in Africa. ${ }^{89}$ Small-scale farmers, who bear responsibility for the majority of Africa's agricultural production, likely will feel the impacts of climate change most significantly, ${ }^{90}$ impinging upon their ability to make food available to the African population. Asia, in contrast, is projected to experience

81. FAO FOOD SECURITY, supra note 46 , at 3.

82. Id.

83. Id.

84. Charles, supra note 17 , at 44 .

85. Id.

86. WREFORD ET AL., supra note 51, at 49.

87. Charles, supra note 17 , at 45.

88. Id.

89. See id.

90. Id. 
increased flooding due to glacier melt in the Himalayas over the next two to three decades, which likely will be followed by decreased river flows as glacier melt recedes. ${ }^{91}$ Accordingly, Asian crop yields are expected to increase up to 20 percent in East and Southeast Asia, while Central and South Asia are expected to experience up to 30 percent decline in crop yields..$^{92}$ This means that, while food availability is projected to increase in some areas of Asia, other areas of Asia will see sharp declines. ${ }^{93}$ In the United States, most estimates predict increases in overall crop yields with likely regional differences. Overall production and availability of food in the United States is projected to remain fairly stable. ${ }^{94}$

In addition to impacts on global food production and availability, climate change could also impact the other three elements of food security: (1) access to food, (2) food stability, and (3) food utilization. Food access relates to whether individuals are able to acquire sufficient amounts of appropriate foods to meet nutritional requirements. ${ }^{95}$ Geographic location is again a critical factor affecting how climate change will impact a particular region's access to food. ${ }^{96}$ Worldwide, the overall volume of available food is projected to remain fairly constant, although agricultural production in developing countries is expected to decrease. ${ }^{97}$ This decrease will significantly impact populations in developing countries where subsistence agriculture is the primary source of livelihood, which is the case for 86 percent of the world's rural people, increasing their risk and vulnerability to food insecurity. ${ }^{98}$

Food stability involves a population's consistent access to adequate food supplies. ${ }^{99}$ In areas where climate variability and frequency or intensity of extreme weather events are predicted to increase, populations' access to and ability to purchase food will likely be compromised, leaving many

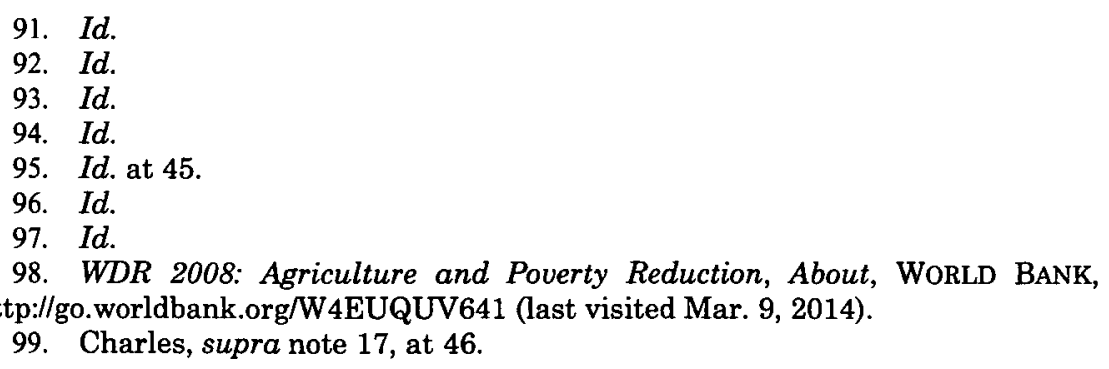


without stable access to food. 100 Most of the areas with predicted increases in climatic fluctuation are in developing regions of the world and, as such, they may not have the technological and socio-economic resources to adapt their agricultural systems to changes in weather conditions. ${ }^{101}$ It is therefore likely that the poorest regions of the world will experience the highest levels of instability in food production. ${ }^{102}$

Food utilization involves an individual's ability to derive essential nutrients from food and convert them into usable human energy without impediments to health, such as poor sanitation, lack of access to clean water, and lack of health care. ${ }^{103}$ A person's capacity for food utilization therefore depends not only on the nutritional value of the foods consumed, but also on the safety of the food supply and the quality of access to determinants of good health. 104 In regions where climate change impacts the ability of agricultural systems to produce quality foods, food utilization will be affected because a low-quality or unsafe food supply may cause individuals to become deficient in essential nutrients and lead to the spread of food-borne diseases. 105 Climate change is expected to directly impact many determinants of health, including access to clean potable water and exposure to extreme weather events and diseases, ${ }^{106}$ and is also expected to produce increased incidence of acute and chronic illnesses and malnutrition. ${ }^{107}$ Food utilization will therefore likely become more difficult to achieve as climate change impacts not only food systems' capacity for producing safe, quality foods, but also individuals' access to good health. ${ }^{108}$ Because the impacts of climate change are expected to be disproportionately experienced by the poorer, more vulnerable regions of the world where barriers to health may already exist, food utilization will

100. FAO FoOD SECURITY, supra note 46 , at 26 .

101. Charles, supra note 17 , at 46 .

102. Id.

103. Id.

104. FAO FOOD SECURITY, supra note 46 , at 21.

105. Id.

106. Lindsay F. Wiley, Mitigation/Adaptation and Health: Health Policymaking in the Global Response to Climate Change and Implications for Other Upstream Determinants, 38 J.L. MED. \& ETHICS 629, 630 (2010).

107. Charles, supra note 17, at 46.

108. FAO FOOD SECURITY, supra note 46 , at 21. 
likely become more difficult to achieve in these areas as climate change affects food systems' capacity to produce quality foods.

Even in the developed world where food security may not be as urgent a concern as in the developing world, climate change impacts have the potential to make some regions unsuitable for growing crops, reduce crop yields in other regions, and require more costly farming practices (such as increased pesticide and fertilizer use and more sophisticated and intensive irrigation and water management systems) to grow crops in other regions. ${ }^{109}$ Moreover, due to the extensive global trade of agricultural products, countries that rely on imports from other regions will be affected regardless of impacts on their domestic production. ${ }^{110}$

\section{Strategies for Addressing Climate Change's Impacts to Agriculture: Mitigation and Adaptation}

Because of the interconnection between agriculture and climate change, it is necessary to find strategies that manage both the impact of agriculture on climate change and the impacts of climate change on agriculture. This Article proposes an approach that integrates climate change mitigation and adaptation in the agricultural setting.

Strategies for managing the impacts of climate change can generally be grouped into two broad approaches: mitigation strategies and adaptation strategies. Mitigation involves avoiding the unmanageable impacts of climate change through policies that seek to reduce net GHG emissions and otherwise lessen the effects of climate change. ${ }^{111}$ Adaptation refers to managing the unavoidable effects of climate change, and within the context of agriculture and food security, adapting our system of agriculture to enable food production under changing climatic conditions. ${ }^{112}$ The majority of strategies employed in the United States to address the impacts of climate change to date have primarily fallen under the category of "mitigation." 113 Research suggests, however, that even if the

109. USGCRP, IMPACT REPORT, supra note 63, at 72-75.

110. Tim Wheeler \& Joachim von Braun, Climate Change Impacts on Global Food Security, 341 SCIENCE 508, 512 (2013).

111. FAO FOOD SECURITY, supra note 46 , at xi.

112. Id.

113. J.B. Ruhl, Climate Change Adaptation and the Structural Transformation 
atmospheric concentrations of GHGs could be stabilized through mitigation measures, climate change's impacts on agricultural production will continue without stabilizing for some time after GHG emissions reach equilibrium. ${ }^{114}$ It is therefore critical that policymakers focus not only on mitigation but also on adaptation in order for agriculture to effectively respond to the impacts of global climate change. 115 This subsection first provides a detailed definition of mitigation within the overall context of climate change before moving to a discussion of strategies proposed to mitigate impacts of climate change on agriculture. A detailed description of adaptation strategies is then provided to set the stage for a discussion of the strategies that have been proposed to adapt agriculture to climate change.

\section{Mitigation Strategies}

The United States Global Change Research Program defines "mitigation" in the climate change context as "options for limiting climate change by, for example, reducing heattrapping emissions such as carbon dioxide, methane, nitrous oxide, and halocarbons, or removing some of the heat trapping gases from the atmosphere."116 As mentioned above, the purpose of mitigation strategies is essentially to avoid the unmanageable consequences of climate change. Mitigation policies therefore seek to slow the rate at which climate change occurs. In the short term, mitigation can be accomplished by reducing GHG emissions and controlling the atmospheric concentrations of such gases through carbon sequestration. Long-term mitigation strategies involve promoting development choices that will produce lower emissions over the coming decades. ${ }^{117}$ As the effects of climate change become

of Environmental Law, 40 ENVTL. L. 363, 374-75 (2010); Robin Kundis Craig, "Stationarity is Dead" - Long Live Transformation: Five Principles for Climate Change Adaptation Law, 34 HARV. ENVTL. L. REV. 9, 18-19 (2010).

114. See Steven K. Rose \& Bruce A. McCarl, Greenhouse Gas Emissions, Stabilization and the Inevitability of Adaption: Challenges for U.S. Agriculture, 23 CHOICES, $1^{\text {st }}$ Quarter 2008, at 15, www.choicesmagazine.org/2008-1/theme/05.pdf.

115. IPCC SUMMARY FOR POLICYMAKERS, supra note 3, at 19.

116. USGCRP, IMPACT REPORT, supra note 63, at 10-11.

117. Brian Fisher et al., Issues Related to Mitigation in the Long Term Context, in Climate ChaNGE 2007: MITIGATION, CONTRIBUTION OF WORKING GROUP III TO the Fourth ASSESSMENT REPORT OF THE INTER-gOVERNMENTAL PANEL ON 
more prevalent, mitigating its impacts will be critical in avoiding drastic increases in global food insecurity. ${ }^{118}$

Within the context of agriculture, mitigation strategies typically seek to reduce emissions and sequester carbon by employing more sustainable and environmentally friendly agricultural practices. ${ }^{119}$ GHG emissions from agriculture can be reduced by improving energy efficiency on the farm, reducing fossil fuel inputs for synthetic fertilizers and pesticides, reducing reliance on fossil fuels to run heavy farm, transportation, and processing equipment, and building local or regional food systems that limit the number of miles traveled for agricultural products. ${ }^{120}$

The Food and Agricultural Organization of the United Nations (FAO) suggests that widespread adoption of mitigation best practices within the agricultural sector could have the collateral effect of improving global food security by increasing market stability, providing agricultural employment opportunities, and boosting the sustainability of vulnerable agricultural systems. 121 The FAO proposes a number of agricultural practices that could be employed to achieve those benefits by contributing to one of three FAO-articulated mitigation goals: (1) reducing carbon dioxide $\left(\mathrm{CO}_{2}\right)$ emissions, (2) reducing methane and nitrous oxide emissions, and (3) sequestering carbon. ${ }^{122}$

According to the FAO, agricultural mitigation practices that could be adopted to achieve the first goal-reduction of $\mathrm{CO}_{2}$ emissions-include: reducing land conversion and deforestation rates, increasing energy efficiency in the commercial agriculture and agro-industrial sectors, and improving control of wildfire and burning associated with agricultural fields. ${ }^{123}$ To achieve the second mitigation goalreduced methane and nitrous oxide emissions associated with

Climate Change 171 (B. Metz et al. eds., 2007), available at http://www.ipcc. ch/pdf/assessment-report/ar4/wg3/ar4-wg3-chapter3.pdf; FAO FOOD SECURITY, supra note 46 , at 8 ; Craig, supra note 113 , at 19 .

118. FAO FOOD SECURITY, supra note 46 , at 59 .

119. Id.

120. John Horowitz \& Jessica Gottlieb, The Role of Agriculture in Reducing Greenhouse Gas Emissions, USDA Economic Brief No. 15 (2010), available at http://www.ers.usda.gov/publications/eb-economic-brief/eb15.aspx\#.U02tE_ldVmc.

121. Id.

122. Id.

123. Id. 
agricultural production-the FAO suggests the adoption of such practices as improving livestock nutrition, increasing management efficiency of wastes from livestock, increasing efficiency of nitrogen fertilizer applications in cultivation, and reclaiming treated wastewater for irrigation and recharge of aquifers. ${ }^{124}$ Agricultural practices that could be employed to achieve the third goal-sequestering carbon-include: improved pasture and grazing management in grasslands, improved management of organic matter in soils, minimized crop rotation and mechanical soil disturbance, increased use of marginal lands for planted forests or cellulosic biomass, planting of trees for carbon sequestration purposes, and the "introduction of integrated agroforestry systems that combine crops, grazing lands and trees in ecologically sustainable ways." 125

In the United States, to date, climate change policy has focused almost exclusively on broad mitigation strategies, and very little attention has been paid on a federal scale to applying these strategies to the agricultural sector. ${ }^{126}$ A majority of the proposed and, in some cases, implemented congressional and state legislation and programs designed to address climate change have done so almost exclusively through mitigation approaches seeking to reduce total GHG emissions. ${ }^{127}$ While the federal government has taken some steps to reduce GHG emissions, federal GHG emissions legislation has largely stalled. ${ }^{128}$ The federal government's limited efforts to regulate GHG emissions generally do not address most agricultural activities, ${ }^{129}$ and consequently, the United States has done very little to promote mitigation strategies in agriculture. Efforts to reduce GHG emissions from agriculture must be specifically

124. $I d$.

125. Id.

126. Craig, supra note 113 , at 18 n.49.

127. Id. at 20 n.54 (noting that in January of 2009, Congress proposed at least eight mitigation-related bills, while "only three bills proposed during the same period even remotely addressed climate change adaptation").

128. Aliza Wasserman, World Resources Inst. Fact Sheet: U.S. Climate Action in 2009-2010, WORLD RESOURCES INST., 1 (Sept. 2010), http://pdf.wri.org/ factsheets/factsheet_us_climate_action_in_2009-2010.pdf.

129. See Prevention of Significant Deterioration and Title V Greenhouse Gas Tailoring Rule, 75 Fed. Reg. 31,514, 31,520 (June 3, 2010); Memorandum of June 25, 2013-Power Sector Carbon Pollution Standards, 78 Fed. Reg. 39,535 (July 1, 2013), available at http://www.gpo.gov/fdsys/pkg/FR-2013-07-01/html/ 2013-15941.htm. 
tailored to address the types of activities that take place in the agricultural world and will not fit neatly into programs designed to address emissions from power plants, factories, and other industrial and commercial activities.

The Intergovernmental Panel on Climate Change (IPCC) reports that "[u]nmitigated climate change would, in the long term, be likely to exceed the capacity of natural, managed and human systems to adapt."130 Mitigation efforts therefore remain critical in the fight to address climate change before mass destruction of natural and human ecosystems occurs. ${ }^{131}$ IPCC also notes, however, the importance of combining mitigation strategies with strategies aimed at adaptation to climate change, stating, "[a]daptation is necessary in the short and longer term to address impacts resulting from the warming."132

\section{Adaptation Strategies}

According to the United States Global Change Research Program, adaptation "refers to changes made to better respond to present or future climatic and other environmental conditions, thereby reducing harm or taking advantage of opportunity."133 Adaptation strategies therefore necessarily assume that climate change-induced hazards will occur to at least some degree and focus on strengthening natural and human systems' capacity to deal with the anticipated changes associated with such hazards. ${ }^{134}$ Adaptation strategies can be divided into two types: proactive and reactive. ${ }^{135}$ Proactive strategies, also referred to as anticipatory or preventative, look ahead to the anticipated impacts of climate change and seek to reduce harm in light of these impacts through measures such as water storage, crop insurance, and disaster risk management. ${ }^{136}$ Reactive strategies, in contrast, involve responses designed in reaction to climate change impacts that are observed as they occur, including emergency and disaster

130. IPCC SUMMARY FOR POLICYMAKERS, supra note 3, at 19 (emphasis in original).

131. Craig, supra note 113 , at 20.

132. IPCC SUMMARY FOR POLICYMAKERS, supra note 3, at 19 .

133. USGCRP, IMPACT REPORT, supra note 63, at 11.

134. Wiley, supra note 106 , at 631 .

135. Ruhl, supra note 113 , at 383.

136. Id. 
response and recovery. ${ }^{137}$

Strategies for adapting agriculture to climate change broadly include a mix of technological strategies and institutional policy changes. Technological adaptations include a wide variety of technological developments, such as: increased crop variety development; 138 innovations in resource management, including water conservation measures; 139 development of forecasting systems; ${ }^{140}$ and technological adoptions, such as: diversification of crop varieties, ${ }^{141}$ development of improved irrigation systems, ${ }^{142}$ and changes in land use and timing. ${ }^{143}$ Proposed institutional and policy changes typically involve increased governmental support for agriculture, including subsidies and incentives. ${ }^{144}$

The FAO articulates three overarching goals of agricultural adaptation: (1) protecting food production systems against increasing variability in weather patterns and frequency or intensity of severe weather events; (2) avoiding disruptive impacts to food supplies from changes in temperature and precipitation patterns; and (3) protecting natural systems through enhanced provision of environmental services. ${ }^{145}$ Specific agricultural adaptation practices that would address the first goal-protecting food systems against changes in weather patterns-include risk management (including management of both general risk and ecosystemspecific risks); research, development, and dissemination of crop varieties bred to be adaptive to changing climate conditions; and the planting of tree crops. ${ }^{146}$ The second goalavoiding disruptions to food supply due to temperature and

137. Id.

138. N.V. Fedoroff et al., Radically Rethinking Agriculture for the 21st Century, 327 SCIENCE 833, 833 (2010).

139. WREFORD ET AL., supra note 51 , at 67.

140. World Development Report 2008: Adaptation and Mitigation of Climate Change in Agriculture, WORLD BANK, 2, http://siteresources.worldbank. org/INTWDRS/Resources/477365-1327599046334/Brief_AdptMitClimateChng_ web.pdf.

141. WREFORD ET AL., supra note 51, at 63.

142. World Development Report, supra note 140, at 2.

143. WREFORD ET AL., supra note 51, at 63.

144. Id. at 64. See, e.g., CAL. NATURAL RES. AGENCY, Agriculture, in 2009 CALIFORNIA CLIMATE ADAPTATION STRATEgY 92, available at http://resources.ca.gov/climate_adaptation/docs/Statewide_Adaptation_Strategy__Chapter_8_-_Agriculture.pdf.

145. FAO FOOD SECURITY, supra note 46 , at 31.

146. Id. 
precipitation shifts - could be addressed through such adaptive agricultural practices as increased efficiency of water management in agriculture (including rice paddy irrigation water), improved management of livestock and cultivated land, and increased technological energy efficiency within the agroindustrial sector. ${ }^{147}$ Finally, several agricultural practices could be employed to accomplish the third goal of agricultural adaptation-protection of ecosystems through enhanced provision of ecosystem services-including planting forests or other cellulosic biomass on degraded or marginalized land; planting trees for carbon sinks; employing watershed protection measures; preventing land degradation; protecting coasts from severe coastal weather hazards; preserving mangrove ecosystems; and conserving biodiversity. 148

Many states in the United States have developed their own climate change adaptation plans. ${ }^{149}$ Some of these address agriculture in specific ways, and some address it only obliquely. However, for the most part, the states' plans for adaptation to climate change are quite modest and contain only very general recommendations. For example, the Alaska plan includes recommendations for additional research on, among other things, the "sources of food supply and the risk associated with high reliance on imported foods" and the development of a "strategic Alaska food policy to increase reliance on locally produced food sources . . . including enhanced intrastate marketing of Alaska-grown products." 150 The California climate adaptation plan devotes an entire chapter to agricultural needs and adaptation strategies, setting forth six broad adaptation strategies and actions. ${ }^{151}$ These include, among other things, water supply planning; land use planning practices that

147. Id.

148. Id.

149. Alaska, California, Connecticut, Florida, Massachusetts, Maine, Minnesota, New Hampshire, New York, Oregon, Pennsylvania, Virginia, Washington and Wisconsin all either have adopted climate adaptation plans or have adaptation plans in development. See U.S. Climate Policy Maps - Climate Adaptation Plans, CTR. FOR Climate \& ENERGY SOlUTIONS, http://www.c2es. org/node/9337 (last visited Aug. 6, 2013).

150. Alaska Adaptation AdVISORY GRP., Alaska's Climate Change STRATEGY: ADDRESSING IMPACTS IN ALASKA (2010) 5-10, available at http://www. climatechange.alaska.gov/aag/docs/aag_all_rpt_27jan10.pdf.

151. Cal. Natural Res. Agency, Agriculture, in 2009 Caltfornta Climate ADAPTATION STRATEGY 92, available at http://resources.ca.gov/climate adaptation/docs/Statewide_Adaptation_Strategy_-_Chapter_8_-_Agriculture.pdf. 
include sustainable and adaptable farmland and farm carbon sequestration; and the promotion of working landscapes with ecosystem services to improve agrobiodiversity. 152

In light of the pervasive uncertainty surrounding the predicted impacts of climate change, it is becoming increasingly necessary for policymakers to restructure their approach to addressing climate change by combining both mitigation and adaptation strategies, for neither one alone will be sufficient to give natural and human systems a chance to survive and adapt to the predicted climatic changes. ${ }^{153}$ The whole-system agricultural certification program proposed in this Article integrates both mitigation and adaptation strategies in an effort to avoid the unmanageable impacts of climate change through practices that reduce emissions and sequester carbon, while at the same time managing the unavoidable impacts of climate change through practices that increase an agricultural system's resilience and adaptive capacity to respond to climate change-induced impacts.

\section{LEARNING FROM ECO-AGRICULTURE: BIODIVERSITY, ECOSYSTEM SERVICES, AND THE COMPONENTS OF A RESILIENT AGRICULTURAL SYSTEM}

In response to the reality that continued environmental degradation and climate change present threats to worldwide agricultural production, many scientists, farmers, environmentalists, and policymakers ${ }^{154}$ have begun to advocate replacing industrialized agriculture with more sustainable approaches to agricultural production. One such approach, ecoagriculture, applies the concept of ecological resilience to increase the agricultural system's capacity to absorb environmental disturbances.

Ecological resilience is based on the understanding that ecosystems are not static entities existing in a single state of equilibrium; instead, ecosystems exist in multiple stable states of gradual change punctuated by shocks or disturbances that

152. See id. at $100-06$.

153. Craig, supra note 113, at 30; Ruhl, supra note 113, at 370 ; IPCC SUMMARY FOR POLICYMAKERS, supra note 3, at 19.

154. See also MCNEELY \& SCHERR, ECOAGRICULTURE: STRATEGIES, supra note 20, at 93. See generally The Nairobi Declaration, supra note 20; SOULE \& PIPER, supra note 20. 
have the potential to reconfigure the entire system. 155 Ecological resilience emphasizes the inherent variability and unpredictability of natural systems by considering the magnitude of disturbance a system can absorb before the shock causes it to shift into another state characterized by different controlling processes. ${ }^{156}$ As such, ecological resilience captures the strengths provided by the interconnected components present in the system, which enhance diversity and redundancy within the system and reinforce its processes and compensating functions. ${ }^{157} \mathrm{~A}$ system's diversity and redundancies thus provide it with an ability to absorb disturbances and persist, despite the disruption, without triggering reconfiguration. 158

In the context of agriculture, resilience describes a farm ecosystem's capacity to absorb shocks or disturbances, such as those associated with the predicted impacts of climate change, which threaten its continued ability to function. ${ }^{159}$ Agricultural resilience is thus necessary for a farm to have the capacity to deal with disturbances or periods of turbulent change. ${ }^{160}$ As described in more detail below, this capacity is largely achieved through the use of strategies that seek to enhance and maintain biodiversity, ecosystem services, and redundancy within a farm ecosystem. ${ }^{161}$ Retaining diversity and redundancy within an agricultural ecosystem enhances the farmer's ability to maintain or even transform the farm in the event that a disturbance event threatening some component of production should arise. ${ }^{162}$ Diversity provides this enhancement by enabling the system to absorb the shock or offering more choices for transformation of the farm enterprise. ${ }^{163}$

Because agricultural resilience is linked to enhanced diversity of all components of the farm system, an ecosystem approach emphasizing the interconnected components of the farm ecosystem is particularly applicable when describing

155. Darnhofer et al., supra note 22, at 187

156. Gunderson et al., supra note 21, at 4.

157. Id. at 6 .

158. Id.

159. Craig, supra note 113 , at 22 .

160. Darnhofer et al., supra note 22, at 187.

161. Id.

162. Id.

163. Id. 
agricultural resilience. Such an approach is employed in the field of eco-agriculture, which can therefore provide many insights into strategies farmers can use to improve a farm system's overall resilience.

In order to transform our system of agricultural production to become more resilient to the impacts of climate change, it is necessary to first understand the concept of ecological resilience and identify specific farming techniques that could increase agricultural resilience. To that end, in this Part of the Article we define the concepts of biodiversity and ecosystem services and review the ways these concepts work together to increase ecological resilience within a system. We then provide a discussion of the ways in which industrialized agriculture inherently lacks resilience, before turning to a discussion of the specific agricultural practices promoted in the field of ecoagriculture designed to increase resilience on the farm.

\section{A. Resilience through Biodiversity and the Provision of Ecosystem Services}

Resilience in natural systems is inextricably linked to system biodiversity and the provision of ecosystem services. ${ }^{164}$ Biodiversity and ecosystem services, both discussed in more detail below, contribute to the resilience of an ecosystem, or its ability to respond to and recover from disturbances or shocks, by providing the diversity and redundancies necessary to allow the system to decrease its vulnerability to disturbances. ${ }^{165}$

One of the most significant factors contributing to the stability and resilience of an ecosystem is biodiversity. ${ }^{166}$ The United Nations Convention on Biological Diversity defines biodiversity as "the variability among living organisms from all sources including, inter alia, terrestrial, marine and other

164. See Michael Jahi Chappell \& Liliana A. LaValle, Food Security and Biodiversity: Can We Have Both? An Agroecological Analysis, 28 AGRIC. HUM. VALUES 3, 14 (2011); Emile A. Frison et al., Agricultural Biodiversity is Essential for a Sustainable Improvement in Food and Nutrition Security, 3 SUSTAINABILITY 238, 246 (2011); Asa Jansson \& Steven Polasky, Quantifying Biodiversity for Building Resilience for Food Security in Urban Landscapes: Getting Down to Business, 15 ECOLOGY AND SOCIETY 20, 33 (2010).

165. Frison et al., supra note 164, at 244.

166. Garry Peterson, Contagious Disturbance and Ecological Resilience (1999) (unpublished Ph.D. dissertation, University of Florida) (on file with George A. Smathers Libraries, University of Florida). 
aquatic ecosystems and the ecological complexes of which they are part: this includes diversity within species, between species and of ecosystems." 167 Individual species preform only limited ecosystem functions. 168 Agricultural monocultures typically have a limited number of species providing a limited number of ecosystem functions. Diverse ecosystems, on the other hand, typically have multiple species carrying out particular ecosystem functions. ${ }^{169}$ The ability of one species to compensate for the loss of a function previously provided by another species impacts the ability of the system to be able to dampen the effects of disturbances. ${ }^{170}$ For example, in an ecosystem with high biodiversity, nature provides a complex system of pest control that has evolved over millions of years. Pests, predators, and parasites of pests develop complex interactions wherein the predators and parasites often function as natural pest-control systems. ${ }^{171} \mathrm{In}$ industrialized agriculture, the use of monoculture planting, synthetic pesticides, and other industrial practices can remove this natural pest control system, which can lead to pest outbreaks. ${ }^{172}$ Biodiversity is therefore critical "to improve productivity, to enhance ecosystem functions, and to provide adaptability" for natural systems adapting to the impacts of climate change. ${ }^{173}$

The concept of "ecosystem services," which refers to the various essential goods and services created and provided by the "interactions of living organisms with their environment," 174 is generating excitement and is becoming increasingly accepted within environmental and economic communities striving to account for the values nature provides humankind. ${ }^{175}$ Ecosystem services describe the myriad of benefits human and natural systems receive from healthy

167. United Nations Convention on Biological Diversity art. 2, June 5, 1992, 2226 U.N.T.S. 208, available at http://www.cbd.int/doc/legal/cbd-en.pdf.

168. Jansson \& Polasky, supra note 164 , at 20.

169. Id.

170. Gunderson et al., supra note 21 , at 9 .

171. H.F. VAN EMden \& M.W. SerVICE, PEST AND Vector CONTROL 38-39 (2004).

172. Id. See also Mary Jane ANGelo, The LaW AND Ecology of Pesticides and Pest Management 42-44 (2013).

173. Frison et al., supra note 164, at 247.

174. J.B. Ruhl \& James Salzman, The Law and Policy Beginnings of Ecosystem Services, 22.2 J. LAND USE \& ENVTL. L. 157, 157 (2007).

175. Id. 
ecosystem function, ${ }^{176}$ including such benefits as pollination and the storage and cycling of water nutrients and carbon. ${ }^{177}$ Ecosystem services are dependent on the variety of species and traits supplied by biodiversity. 178 The goods and services that human populations derive from ecosystem functions include such vital services as maintenance of biodiversity, disease regulation, climate stabilization, air and water purification, soil formation, water flow regulation, pollination of vegetation and crops, and spiritual and aesthetic enjoyment. ${ }^{179}$

The total value of these global ecosystem services, while difficult to quantify, is undoubtedly extremely high. ${ }^{180}$ Some experts have estimated the values of global ecosystem services to be as high as $\$ 33$ trillion per year. ${ }^{181}$ Although most of the planet's ecosystem services are currently undervalued or have no economic value at all within the marketplace, 182 ecosystem services are critical to the support and function of the planet, ${ }^{183}$ contribute considerably to human welfare, ${ }^{184}$ and therefore represent a significant portion of the planet's total economic value. ${ }^{185}$ Unfortunately, the 2005 Millennium Assessment Report estimated that over 60 percent of the world's ecosystem services are currently being degraded faster than they can recover. ${ }^{186}$ This damage to ecosystem services produces

176. Richard Tingem Munang et al, Ecosystem Management: Tomorrow's Approach to Enhancing Food Security Under a Changing Climate, 3 SUSTAINABILITY 937, 938 (2011).

177. Id.

178. Jansson \& Polasky, supra note 164 , at 20.

179. Katoomba Group, Payments FOR Ecosystem Services, Getting STARTED: A PRIMER 2 (May 2008), available at http://www.katoombagroup. org/learning_tools.php.

180. Robert Costanza et al., The Value of the World's Ecosystem Services and Natural Capital, 387 NATURE 253, 253 (1997).

181. Id. at 259 (assessing the total value of ecosystem services as approximately 1.8 times the then-current world gross national product (GNP)).

182. KATOOMBA GROUP, supra note 179 , at 2.

183. See generally MILLENNIUM ECOSYSTEM ASSESSMENT, ECOSYSTEMS AND HUMAN WELL-BEING: SYNTHESIS (2005), available at http:// millenniumassessment.org/documents/document.356.aspx.pdf. This report relied on contributions from over 1,360 experts from over ninety-five countries and represented the first attempt by the scientific community to provide a global assessment of the full range of benefits provided to humans by nature.

184. Costanza et al., supra note 180 , at 253.

185. Id.

186. MILLENNIUM ECOSYSTEM ASSESSMENT, supra note 183, at 6 (indicating that over the past fifty years essential ecosystem services such as air quality regulation, climate regulation, erosion regulation, supply of water, capture fishery 
substantial economic and public health $\operatorname{costs}^{187}$ and has implications for food security. ${ }^{188}$

Effective management of ecosystems to promote biodiversity can increase the planet's provision of the ecosystem services that are so vital to human and ecological existence. 189 The term "agricultural multifunctionality" describes the integration of ecosystem services and agriculture to achieve this result. ${ }^{190}$ In the context of agriculture, "[m]ultifunctionality . . recognizes that farms and ranches produce more than just commodities; they also produce a wide array of environmental goods and services."191 In other words, multifunctionality emphasizes the notion that agricultural lands can be managed to produce not only food and fiber commodities but ecosystem services as well. ${ }^{192}$ Agricultural land supplies society with a variety of ecosystem services, including the maintenance of open spaces, environmental protection, water storage, maintenance of biodiversity, and protection of natural habitat. ${ }^{193}$

Because ecosystem services support many aspects of agricultural production, sustaining biodiversity to promote ecosystem service provision is critical for ensuring global food security. 194 Biodiversity essentially acts as an agricultural system's insurance policy against disturbances by enhancing provision of ecosystem services and therefore improving the system's overall resilience. ${ }^{195}$ The enhanced resilience provided by this insurance policy has important implications for food

provision, purification of water, protection against natural hazards, and treatment and detoxification of water have been degraded).

187. Id.

188. Munang et al., supra note 176 , at 938.

189. R. K. Turner \& G. C. Daily, The Ecosystem Services Framework and Natural Capital Conservation, 39 ENVTL. RESOURCE ECON. 25, 25-26 (2008).

190. N. Jordan et al., Sustainable Development of the Agricultural BioEconomy, 316 SCI. 1570, 1570 (2007).

191. William J. Even, Green Payments: The Next Generation of U.S. Farm Programs?, 10 DRAKE J. AGRIC. L. 173, 190 (2005).

192. J.B. Ruhl, Agriculture and Ecosystem Services: Strategies for State and Local Governments, 17 N.Y.U. ENVTL. L.J. 424, 432-33 (2008).

193. E.A. Machado et al., Prioritizing Farmland Preservation Cost-Effectively for Multiple Objectives, $61 \mathrm{~J}$. SOIL \& WATER CONSERVATION 250, 250 (2006).

194. Robert B. Richardson, Ecosystem Services and Food Security: Economic Perspectives on Environmental Sustainability, 2 SUSTAINABILITY 3520,3545 (2010).

195. Chappell \& LaValle, supra note 164, at 14. 
security. ${ }^{196}$ Diversity and ecosystem services affect food security by directly impacting an agricultural system's ability to produce food (i.e., food availability), ${ }^{197}$ to provide resources that individuals can use to generate income and improve livelihoods (i.e., food access), 198 and to produce resources necessary for healthy, safe food production (i.e., food utilization). ${ }^{199}$ A healthy, functioning agro-ecosystem is better situated to absorb climate change-induced disturbances than a system wherein biodiversity and ecosystem service provision have been degraded.200 As the Millennium Ecosystem Assessment emphasized, biodiversity and ecosystem services are crucial in supporting agricultural production, and, as such, healthy ecosystems can be seen as essential to the achievement of food security. ${ }^{201}$ Eco-agriculture, described in more detail below, is an agricultural approach that seeks to maintain and enhance an agro-ecosystem's biodiversity and ecosystem service provision; eco-agriculture has therefore been suggested as a method that should be employed to achieve food security. ${ }^{202}$

\section{B. Industrial Agriculture: Non-Diverse and Non-Resilient}

The modern industrialized agricultural system in place throughout the majority of our planet, with its emphasis on monocultures and chemical inputs, largely ignores biodiversity and provision of ecosystem services, despite their importance in maintaining a healthy agro-ecosystem. Humans developed agriculture more than 10,000 years ago. Up until relatively recently, humans farmed in ways that capitalized on ecosystem services such as pest control via natural predators and parasites, the use of animal and plant waste as fertilizer, and practices that maintained biodiversity on the farm. ${ }^{203}$ In contrast, modern industrialized agriculture typically involves vast areas of monoculture planting, coupled with reliance on

196. Munang et al., supra note 176 , at 938 .

197. Richardson, supra note 194 , at 3531.

198. Id. at 3535 .

199. Id. at 3540 .

200. Id.

201. Id. at 3545 .

202. Munang et al., supra note 176 , at 950 .

203. See MCNEELY \& SCHERR, ECOAGRICULTURE: STRATEGIES, supra note 20, at 47; VAN EMDEN \& SERVICE, supra note 171, at 123-35. 
fossil fuel-derived synthetic pesticides and fertilizers. ${ }^{204}$ This emphasis on monocultures and chemical inputs (as described in more detail below) contributes to industrialized agricultural systems' inherent non-diversity and non-resilience. ${ }^{205}$

Industrialized agriculture's widespread use of monocultures eliminates biodiversity and thus, the natural forces that can keep pest populations in check. In the past, pest population control was facilitated by practices that maintained diversity on the farm via intercropping, ${ }^{206}$ crop sequencing, or crop rotation. ${ }^{207}$ Without the natural pest control that comes with a diverse ecosystem, today's large monoculture farms are heavily dependent on chemical pesticide inputs to control pests. ${ }^{208}$ Ironically, the use of chemical pesticides to control pests has led to the creation of new pests and, in some cases, increased pest outbreaks. ${ }^{209}$ Less than 0.1 percent of the chemical pesticides sprayed on a farm field actually reach the target pests. ${ }^{210}$ The vast majority of the pesticides go into the environment where they come into contact with non-target species, often including beneficial predatory or parasitic organisms that normally keep pest populations in check. ${ }^{211}$

Another non-resilient feature of industrialized agriculture's reliance on chemical pesticides is that the use of pesticides can lead to the development of pesticide resistance in pest populations. ${ }^{212}$ When a population of pests is exposed to a particular chemical pesticide, the pesticide will kill the individual pests that are most susceptible to the particular pesticide, and the least susceptible individuals will survive. ${ }^{213}$ Thus, when those pesticide-resistant individuals reproduce,

204. Food and Agriculture, UNION of CONCERNED SCIENTISTS, http://www. ucsusa.org/food_and_agriculture/our-failing-food-system/industrial-agriculture/ (last visited Sept. 14, 2013).

205. Jonathan Foley, Farming Changes Can Limit Risks, N.Y. TTMES, July 25, 2012, http://www.nytimes.com/roomfordebate/2012/07/25/how-can-weprevent-another-dust-bowl/farming-changes-can-limit-risks-of-extreme-drought.

206. Intercropping is the practice of growing two or more crops at the same time. Glossary: Intercropping, FOOD \& AGRIC. ORG., http://www.fao.org/ docrep/x5648e/x5648e0m.htm (last visited Oct. 10, 2013).

207. VAN EMDEN \& SERVICE, supra note 171, at 41-42, 45-46, 139-41.

208. Id. at $41-42$.

209. Id. at 41.

210. Id.

211. David Pimentel and Lois Levitan, Pesticides: Amounts Applied and Amounts Reaching Pests, 36 BIOSCIENCE 86, 86-89 (1986).

212. VAN EMDEN \& SERVICE, supra note 171, at 114-19.

213. Id. at 115-16. 
their offspring will be comprised of a higher proportion of resistant individuals and a lower proportion of susceptible individuals. ${ }^{214}$ When the new, more resistant population is sprayed with the pesticide again, the process will be repeated and subsequent generations will be comprised of even more pesticide-resistant individuals, creating a treadmill effect, where more and more pesticides are needed to keep up with the ever increasingly pesticide-resistant pest populations. ${ }^{215}$

Monoculture farming also eliminates ecological resilience from the farm. ${ }^{216}$ In diverse ecosystems, pests must expend energy to find food sources. 217 Industrialized agricultural monocultures, on the other hand, provide ideal conditions for pest population growth. ${ }^{218}$ Food sources for a particular pest are readily available in great abundance; thus, pests do not have to expend energy or travel distances to find their favored food. ${ }^{219}$ For example, corn ear worms present in a large corn monoculture have virtually unlimited food readily available, which can result in accelerated population growth of the pest. Because of the non-diversity inherent in monoculture farming, attempts to increase resilience in agriculture through such approaches as eco-agriculture (discussed in more detail below) largely discourage monoculture practices in favor of practices that contribute to overall diversity on the farm.

\section{Eco-Agriculture: Enhancing Biodiversity and Ecosystem Services in Agricultural Systems}

In response to the environmental issues associated with industrialized agriculture's non-diversity and non-resilience, a growing body of scholarship emphasizing the application of an ecosystem approach to agricultural production-an approach known as "eco-agriculture"-seeks to promote agricultural sustainability through the use of farming practices that employ the concept of the farm as a healthy, sustainable living system, not an industrial production facility. ${ }^{220}$ Eco-agriculture seeks to

214. Id.

215. Id.

216. Id. at 41.

217. Id.

218. Id. at 41,139 .

219. Id. at 41 .

220. See MCNEEly \& SCHERR, ECOAGRICULTURE: STRATEGIES, supra note 20, at 93. See generally SOULE \& PIPER, supra note 20. 
improve land management, agricultural production, and management of natural resources by accomplishing three goals: (1) conservation and enhancement of biodiversity and ecosystem services; (2) sustainable production of agricultural products and services; and (3) promotion of viable livelihoods for local people.221 In contrast to traditional industrialized agricultural practices, which actively work against nature by purposely decreasing biodiversity in order to promote monocultural production, eco-agriculture seeks to "farm in nature's image,"222 using and managing all the elements of the farm ecosystem to promote biodiversity and provision of ecosystem services. ${ }^{223}$ Eco-agriculture practices thus increase an agricultural system's resilience by promoting diversity through the maintenance and enhancement of the health and function of all components of the farm ecosystem. ${ }^{224}$ The ecosystem functions maintained and enhanced include the maintenance of fertile soils; management of populations of natural predators, pollinators, and parasites; and promotion of biodiversity. 225

Eco-agriculture approaches have three key characteristics in common: (1) application of a landscape-scale view; (2) emphasis on fostering interactions between conservation, agricultural production, and maintenance of rural livelihoods; and (3) emphasis on the importance of conservation in agricultural systems. ${ }^{226}$ The first characteristic-application of a landscape scale - captures the importance of understanding large-scale interactions between different ecosystems and land uses across the landscape in order to effectively promote biodiversity and sustainability. 227 The second characteristic emphasizes the importance of fostering interactions between conservation, agricultural production, and rural livelihoods in order to build a sustainable system of production that is

221. Louise E. Buck et al., Understanding Ecoagriculture: A Framework for Measuring Landscape Performance, ECOAGRICULTURE PARTNERS, 1 (2006), available at $\mathrm{http}: / / \mathrm{www} . e c o a g r i c u l t u r e . o r g / d o c u m e n t s / f i l e s / d o c \_25 . p d f$.

222. SOULE \& PIPER, supra note 20 , at ix.

223. Id.

224. MCNEELY \& SCHERR, ECOAGRICULTURE: STRATEGIES, supra note 20, at 109.

225. Id.

226. Id. at 2 .

227. Id. 
environmentally, economically, and socially beneficial. ${ }^{228}$ The third characteristic recognizes the importance of conservation and enhancement of ecosystem services and biodiversity through the use of conservation-oriented agricultural strategies that promote both environmental sustainability and rural livelihoods. 229

The eco-agriculture approach employs six overarching natural resource management strategies to promote biodiversity. ${ }^{230}$ Three strategies focus on the agricultural production aspect of eco-agriculture: (1) minimization of agricultural wastes and pollution; (2) management of resources for conservation of water, soils, flora, and fauna; and (3) use of vegetation that mimics surrounding natural habitats' ecological structure and function. ${ }^{231}$ The other three strategies apply to management of the landscape surrounding agricultural production areas: (1) minimized conversion of natural areas; (2) protection and expansion of large natural habitat areas of high ecological quality; and (3) the development and maintenance of effective ecological networks and corridors. ${ }^{232}$

To achieve the natural resource management strategies described above, eco-agriculture employs farming techniques designed to enhance both agricultural production and conservation of biodiversity and ecosystem services. ${ }^{233}$ To minimize agricultural wastes and pollution, eco-agriculture encourages reduced and improved use of fertilizers, use of integrated pest management, minimization of runoff through improved storage and filtration, and use of buffer zones to filter pollutants before they enter the watershed.234 To conserve water, soil, floral, and faunal resources, eco-agriculture encourages water reduction and reuse, crop rotation, planting of cover crops, soil enrichment, intercropping, organic production, and maintenance of refugia. ${ }^{235}$ Techniques

228. Id.

229. Id.

230. Id. at 115-90; Sara J. Sherr \& Jeffrey A. McNeely, Biodiversity Conservation and Agricultural Sustainability: Towards a New Paradigm of 'Ecoagriculture' Landscapes, 363 PHIL. TRANSACTIONS RoYAL SOC’Y B 477, 481 (2008) [hereinafter Biodiversity Conservation].

231. Biodiversity Conservation, supra note 230 , at 481 .

232. Id.

233. MCNEELY \& SCHERR, ECOAGRICULTURE: STRATEGIES, supra note 20, at 6.

234. Id. at $150-55$.

235. Id. at $162-67$. 
designed to enhance the health of the landscape surrounding agricultural areas include minimal conversion of natural areas for farming, protection and expansion of high quality natural habitats, and the development of effective ecological networks and biological corridors. ${ }^{236}$

We can gain an understanding of the components that an agricultural system should strive to develop and maintain in order to increase its resilience using the lessons learned from eco-agriculture regarding practices that enhance diversity and resilience. Strategies that maintain and promote biodiversity and provision of ecosystem services are of key importance to a farm's increased resilience. ${ }^{237}$ A resilient system is one in which the health and function of natural resources and their attendant ecosystem services is maintained. ${ }^{238}$ Farmers can employ numerous techniques to enhance biodiversity on their lands, including conservation of natural habitats, intercropping, integrated pest management, and maintenance of refugia, ${ }^{239}$ among many others. ${ }^{240}$

Another key aspect of agricultural sustainability involves both the sustainability of the materials and resources used in agricultural production, such as energy, and the sustainable disposal of agricultural wastes. ${ }^{241}$ A resilient agricultural system should therefore employ practices that reduce fossil fuel inputs; use sustainably derived materials; and reduce, recycle, and dispose of wastes in an environmentally sound manner. ${ }^{242}$

236. The techniques employed in eco-agriculture all help to build diversity within the agricultural system, making it more able to absorb change and thereby increasing its resilience. Although not the focus of this Article, it should be noted that eco-agriculture also encompasses a social or livelihood component, which encourages the support and maintenance of livelihoods through practices that promote acceptable labor conditions and protect worker health and safety. MCNEElY \& SCHERR, ECOAGRICULTURE: STRATEGIES, supra note 20, at 115-90. See also Biodiversity Conservation, supra note 230, at 481 .

237. Biodiversity Conservation, supra note 230, at 480 .

238. MCNEELY \& SCHERR, ECOAGRICULTURE: STRATEGIES, supra note 20, at $13-14$.

239. "Refugia are essentially pesticide-free crop sanctuaries for the sensitive pest population." Trevor V. Suslow, Pest Resistance Management, UNIV. CAL. DAVIS VEGETABLE RESEARCH INFO. CTR. (Feb. 14, 1998), http://vric.ucdavis. edu/pdf/biotechnology_pestresistancemgmt.pdf. Farms that provide refugia minimize the risk of developing pesticide resistance. Id.

240. Biodiversity Conservation, supra note 230, at 481.

241. COMM. ON TWENTY-FIRST CENTURY SYS. AGRIC., TOWARD SUSTAINABLE AGRICULTURAL SYSTEMS IN THE 21ST CENTURY 6-7, 90-92, 95-96 (2010).

242. Id. at 6-7, 122-34. 
Another aspect of agricultural resilience involves protection of the landscape surrounding agricultural production areas; a resilient system should therefore strive to protect landscape connectivity through practices that limit land conversion, maintain biological corridors, and avoid pollution of neighboring ecosystems. ${ }^{243}$ Finally, a resilient agricultural system must necessarily maintain the health and function of its human components through practices that protect worker health, safety, and economic wellbeing. ${ }^{244}$ A resilient system is therefore one that actively seeks to protect the health and function of all its components, including those at the landscape and social levels. ${ }^{245}$

\section{EXISTING APPROACHES TO PROMOTING SUSTAINABLE AGRICULTURE: ECO-LABELING AND ORGANIC CERTIFICATION}

The importance of consumer choice in shifting toward a more sustainable system of agricultural production cannot be denied. ${ }^{246}$ Consumer decisions about which foods to purchase not only affect aspects of individual health, but also shape the agricultural market and its impacts on the environment. ${ }^{247}$ As the recent widespread growth in the organic foods market demonstrates, ${ }^{248}$ consumer interest in safe and sustainable food is growing such that today's consumers are more willing than consumers in previous decades to pay a premium for the health and environmental benefits of foods grown without

243. Id. at 6-7; SOULE \& PIPER, supra note 20, at 150-52.

244. COMM. ON TWENTY-FIRST CENTURY SYS. AGRIC., supra note 241 , at 6-7, $202-07$.

245. Biodiversity Conservation, supra note 230, at 491.

246. See generally Czarnezki, supra note 25.

247. Id. at 4. See also Philip H. Howard \& Patricia Allen, Beyond Organic and Fair Trade? An Analysis of Ecolabel Preferences in the United States, 75 RURAL SoC. 244, 249 (2010) (noting that "[i]ncreasing sales of certified organic products ... have encouraged alternative production practices on a growing number of acres worldwide, leading to the elimination of synthetic pesticide and fertilizer applications on these lands").

248. See Douglas H. Constance \& Jin Young Choi, Overcoming the Barriers to Organic Adoption in the United States: A Look at Pragmatic Conventional Producers in Texas, 2 SUSTAINABILITY 163, 164 (2010) (noting that despite the fact that United States organic production has more than doubled over the past two decades, the market for organic products continues to increase such that the United States currently imports products meeting USDA organic standards in order to meet consumer demand). 
pesticides. $^{249}$

Studies show that certification programs and informational labeling can be effective ways to educate and encourage consumers to make environmentally friendly choices. ${ }^{250}$ Such programs, which can be characterized broadly as "eco-labeling" efforts, present consumers with product labels indicating that the product was produced in accordance with specific ethical or ecological criteria. ${ }^{251}$ Organic certification and eco-labeling programs have been established in both the United States and the European Union. 252 The United States National Organic Program (NOP), ${ }^{253}$ established by the 1990 Organic Foods Production Act, ${ }^{254}$ allows agricultural products to be labeled as "organic" if they are produced without the use of synthetic pesticides and other synthetic substances. In contrast, European Union organic production and labeling regulations go beyond the United States' rather limited approach to encompass additional environmental criteria involving pollution, humane treatment of animals, and biodiversity concerns. ${ }^{255}$ Eco-labeling programs addressing more targeted environmental concerns, such as carbon footprint and "country of origin" labeling, are being developed

249. Ana Maria Aldanondo-Ochoa \& Carmen Almansa-Saez, The Private Provision of Public Environment: Consumer Preferences for Organic Production Systems, 26 LAND USE POL'Y 669, 673 (2009). Research into consumers' willingness to pay for organic products suggests that much of consumer preference is likely driven by health concerns regarding pesticide residues, not necessarily by environmental concerns. Nevertheless, the ancillary benefits of organic, pesticide-free agriculture accrue to the natural environment, producing both a healthier and more sustainable food system. Id. at 671 .

250. See Czarnezki, supra note 25, at 4 (noting that recent scholarship suggests that informational labeling can be an effective method of encouraging consumers to choose eco-friendly products). See also Howard \& Allen, supra note 247 , at 245 (discussing how the mainstream adoption of eco-labels by corporations such as Wal-Mart and McDonald's indicates that consumers increasingly use eco. labels in making decisions about which products to purchase).

251. Introduction to Eco-Labels and Standards, Greener Products, U.S. ENVTL. PROT. AGENCY, http://www.epa.gov/greenerproducts/standards/index.html (last visited Oct. 26, 2013); Howard \& Allen, supra note 247, at 245. See also Richard B. Stewart, A New Generation of Environmental Regulation?, 29 CAP. U. L. REV. 21, 136 (2001) (discussing the concept of eco-labeling).

252. Czarnezki, supra note 25 , at 6 .

253. 7 C.F.R. $\$ 205$ (2013).

254. The OFPA was passed as Title XXI of the 1990 Farm Bill. Food, Agriculture, Conservation, and Trade Act of 1990, Pub. L. No. 101-624, §§ 21012123,104 Stat. 3359, 3935-3951 (codified at 7 U.S.C. $\$ \S 6501-6523$ (2013)).

255. Czarnezki, supra note 25, at 6. 
with varying degrees of success in both the United States and abroad.256

Given the importance of consumer choice in shaping agricultural practices and markets, any drastic shift toward increased sustainability in our agricultural production system should necessarily give serious consideration to the issue of how to inform and educate consumers about the health and environmental benefits of products grown under the new sustainable system. The following Part provides an overview of existing programs, starting with organic certification in both the United States and European Union before moving to a discussion of more targeted eco-labeling programs.

\section{A. Organic Labeling Programs}

Organic agriculture seeks to promote ecological processes that enhance plant health and nutrition while simultaneously conserving soil and water resources by eliminating the use of pesticides and synthetic substances. ${ }^{257}$ The International Federation of Organic Agriculture Movements ${ }^{258}$ (IFOAM), a grassroots international organization that includes seven hundred and fifty member organizations representing over one hundred countries, defines organic agriculture as a "production system that sustains the health of soils, ecosystems and people. It relies on ecological processes, biodiversity and cycles adapted to local conditions, rather than the use of inputs with adverse effects." 259 The currently flourishing market for organic foods is a direct result of regulations establishing organic production labeling programs, which, particularly in the United States, have largely accomplished their goal of increasing organic foods' market share. ${ }^{260}$

256. See generally Czarnezki \& Prescott, supra note 14.

257. David Pimentel et al., Environmental, Energetic, and Economic Comparisons of Organic and Conventional Farming Systems, 55 BIOSCIENCE 573, 573 (2005).

258. INT'L FED'N ORGANIC AGRIC. MOVEMENTS, http://www.ifoam.org/home (last visited Oct. 26, 2013).

259. Definition of Organic Agriculture, INT'L FED'N ORGANIC AGRIC. MOVEMENTS, http://www.ifoam.org/en/organic-landmarks/definitionorganic-agriculture (last visited Oct. 26, 2013).

260. Margot J. Pollans, Bundling Public and Private Goods: the Market for Sustainable Organics, 85 N.Y.U. L. REV. 621, 640, 642 (2010) (discussing original regulatory goal of OFPA as a tool for increasing market expansion). 


\section{The United States Organic Food Production Act and National Organic Program}

The United States' organic certification program is administered under the Organic Foods Production Act (OFPA) ${ }^{261}$ and the NOP, ${ }^{262}$ which was adopted pursuant to the OFPA. The United States Department of Agriculture (USDA) National Organic Standards Board (NOSB) defines "organic agriculture" as "an ecological production management system that promotes and enhances biodiversity, biological cycles and soil biological activity."263 The OFPA establishes a voluntary federal program wherein agricultural producers can opt to have their product USDA-certified and labeled as "organic" if production, handling, and labeling of the product were performed in accordance with standards developed by USDA under the NOP. ${ }^{264}$ Program standards prohibit the use of synthetic pesticides, fertilizers, antibiotics and growth hormones in livestock, and other synthetic ingredients. ${ }^{265}$

Production of organic agricultural products must occur in accordance with an Organic Plan approved by a NOP certifying agent and agreed to by the product producer or handler. ${ }^{266}$ The Organic Plan must include a strategy for soil management that addresses the use of manure and the maintenance of soil fertility, ${ }^{267}$ as well as the minimization of erosion and

261. Organic Foods Production Act, 7 U.S.C. § 6504(1)-(3) (2012).

262. National Organic Program, U.S. DEP'T AGRIC., AGRIC. MARKETING SERV., http://www.ams.usda.gov/AMSv1.0/nop (last visited Oct. 26, 2013).

263. Organic Production and Organic Food: Informational Access Tools, U.S. DEP'T AGRIC., NAT'L AGRIC. LIBRARY, http://www.nal.usda.gov/afsic/pubs/ ofp/ofp.shtml (last visited Oct. 26, 2013).

264. The OFPA directs the Secretary of Agriculture to establish a National Organic Program (NOP), 7 U.S.C. $§ 6503$ (a) (2013), and a National Organic Standards Board (NOSB) to advise the Secretary regarding program standards. Id. $\S 6518(\mathrm{a})$. All producers and handlers of organic goods who gross over $\$ 5,000$ per year are subject to the Act. Id. $\S 6505(\mathrm{~d})$. Small-scale farmers can avoid the certification process by signing a declaration of compliance that their practices meet organic standards, provided they gross less than $\$ 5,000$ per year and sell goods to consumers directly through such venues as farmers markets and stands. Czarnezki, supra note 25 , at 16 . Small farmers seeking to avoid certification through this provision are prohibited from using the "certified organic" label if they sell their products through conventional distribution channels without also becoming officially certified. Id.

265. 7 U.S.C $\S \S 6508(b)(1), 6509$ (c)(3), 6510 (2013).

266. Id. $\S \S 6504-6505$.

267. Id. $\S 6513(\mathrm{~b})(1)-(2)$. 
management of nutrients. ${ }^{268}$ The OFPA also limits organic production to lands with distinct buffer zones that have not been treated with any prohibited substances in the three years prior to harvest. ${ }^{269}$ OFPA requires producers and handlers of organic products to undergo product residue testing 270 and annual on-site inspections. ${ }^{271}$ Specific agricultural practices that can be harmful to the environment are prohibited, including the application of naturally occurring poisons such as lead and arsenic; 272 the use of genetically modified organisms, ${ }^{273}$ sewage sludge, ${ }^{274}$ and ionizing radiation; 275 and the long-term use of plastic mulches. ${ }^{276}$ Only goods achieving NOP certification in accordance with OFPA are permitted to use the organic label. ${ }^{277}$

Agricultural products certified under the NOP are labeled according to a four-tiered system based on the percentage of organic ingredients contained in the product. ${ }^{278}$ Under the first tier, a product containing 100 percent organic ingredients (as defined under OFPA) may be labeled as "100 percent organic" and may carry the official seals of the USDA and certifying agent. ${ }^{279}$ The second tier permits products containing at least 95 percent organically-produced ingredients to be labeled as "organic" and to carry the USDA and private certifying agent seals. ${ }^{280}$ Products containing at least 70 percent organic ingredients may be labeled as "made with organic ingredients" under the third tier, and such products carry the private certifying agent seal. ${ }^{281}$ Finally, products that contain less than 70 percent organically produced ingredients may not use the word "organic" or carry any seal, but are permitted to list

268. 7 C.F.R. $\S 205.203(a)-(b)(2013)$.

269. Id. $\S 205.202(\mathrm{~b})-(\mathrm{c})$.

270. 7 U.S.C. $\$ 6506(a)(6)(2013)$.

271. Id. §6506(a)(5).

272. Id. $\$ 6508(\mathrm{c})(1)$.

273. 7 C.F.R. $\S 205.2$ (2013).

274. Id. $\S 205.105(\mathrm{~g})$.

275. Id. § $205.105(f)$.

276. 7 U.S.C. $\$ 6508(\mathrm{c})(2)(2013)$.

277. Id. $\S 6505(\mathrm{a})(1)(\mathrm{A})-(\mathrm{B})$ (implying that use of the organic label without complying with the specifications of the Act is a violation of the law).

278. 7 C.F.R. $\$ 205.301$ (2013).

279. Id. $\$ \S 205.301(\mathrm{a}), 205.303$.

280. Id. $\S \S 205.301(\mathrm{~b}), 205.303$.

281. Id. § $205.301(\mathrm{c})$. 
organic ingredients on their labels. ${ }^{282}$ The NOP "organic" label informs consumers that products bearing the label were grown without the use of synthetic fertilizers and pesticides. The organic label falls short, however, in that it fails to inform the consumer whether the product was grown using environmentally harmful practices such as intensive fossil fuel use, intensive water use, poor nutrient management, or other practices that result in air or water pollution.

\section{The European Union Organic Program}

The European Union also has established organic production and labeling legislation containing production, labeling, and import requirements for organic goods. ${ }^{283}$ In contrast to the United States' organic certification rules, which specify only that a product was grown without the use of prohibited substances, the European Union organic farming regulations encompass a broader set of environmental concerns by addressing additional criteria involving aspects of sustainability, such as pollution, renewable energy, humane treatment of animals, and biodiversity concerns. ${ }^{284}$

Under the European regulations, products produced and handled in accordance with the specifications of the European Union's organic production and labeling legislation are permitted to carry the specific European Union organic logo. ${ }^{285}$ A food product must contain at least 95 percent organic agricultural ingredients, however, to be labeled "organic" and display the logo. ${ }^{286}$ As in the United States, food products that do not meet this 95 percent threshold, while prohibited from carrying the organic label, are permitted to list organic ingredients on their label. ${ }^{287}$

Although the European Union organic program addresses a broader range of environmental concerns than does the

282. Czarnezki, supra note 25 , at 16 .

283. Legislation, Organic Farming, EUROPEAN COMM'N, http://ec.europa.eu/ agriculture/organic/eu-policy/legislation_en (last visited Oct. 26, 2013).

284. Council Regulation 834/2007, On Organic Production and Labelling of Organic Products and Repealing Regulation (EC) No. 2092/91, 2007 O.J. (L 189) 1 (EC).

285. Czarnezki, supra note 25, at 17.

286. Legislation, supra note 283; Council Regulation 834/2007, 2007 O.J. (L 189) 1 (EC).

287. Legislation, supra note 283. 
United States NOP, it is not designed to address sustainability or resilience of the agricultural systems as a whole.

\section{B. Other Eco-Labeling Efforts}

In addition to eco-labels for organic agricultural production, a variety of other labeling programs exist to inform consumers about environmental concerns, such as carbon emissions and product place of origin, and also about issues tied to the production of specific products, such as coffee and tuna. 288 For example, carbon-footprint labels provide consumers with information regarding the carbon emitted during the production of a particular product. ${ }^{289}$ A product's carbon footprint is determined by using carbon data assessed at all stages of the product's production, from raw materials to finished product. ${ }^{290}$ Carbon-footprint labels seek both to influence consumers to choose products that are more environmentally friendly and to encourage manufacturers to adopt production processes that result in fewer carbon emissions. ${ }^{291}$ While no federal carbon-labeling legislation has been enacted in the United States to date, some states and nonprofit organizations have developed carbon labels for both agricultural and non-agricultural products. ${ }^{292}$ Both New York and California, for example, have developed labeling programs that provide consumers with carbon emission information for new motor vehicles, ${ }^{293}$ and non-profits such as Carbonfund.org ${ }^{294}$ have created their own carbon labels. In Europe, carbon-footprint labeling has gained more widespread traction through the efforts of The Carbon Trust, which has created a "Reducing $\mathrm{CO}_{2}$ Label" and a " $\mathrm{CO}_{2}$ Measured Label" to inform consumers of the carbon footprint associated with a product or service. 295

288. Czarnezki, supra note 25, at 14 .

289. Stacey R. O'Neill, Consuming for the Environment: A Proposal for Carbon Labels in the United States, 39 CAL. W. INT'L L.J. 393, 396 (2009).

290. Czarnezki, supra note 25, at 19.

291. Id.

292. Id. at $19,20$.

293. See CAL. HEALTH \& SAFETY CODE § 43200.1 (2010); N.Y. ENVTL. CONSERV. LAW $\S 19-1103$ (2010).

294. CARBONFUND.oRG, http://www.carbonfund.org/ (last visited Oct. 26, 2013).

295. Carbon Footprint Labels, CARBON TRUST, http://www.carbontrust. com/client-services/footprinting/footprint-certification/carbon-footprint-label (last 
The United States has enacted country of origin labeling (COOL) legislation requiring retailers to provide consumers with information regarding the source country of specific food products. ${ }^{296}$ Only certain specified food products, such as specific meats, vegetables, fruits, and nuts, are subject to COOL legislation. ${ }^{297}$ The purpose of COOL is to promote domestic products and improve food safety, but COOL also allows consumers to take information that may have environmental implications, such as the distance a food product has traveled, into account when choosing which products to purchase.298 The United States' COOL requirements were first enacted under the 2002 Farm Security and Rural Investment Act (Farm Bill) ${ }^{299}$ and its implementing regulations ${ }^{300}$ and were amended by the 2008 Farm Bill. ${ }^{301}$

In addition to the organic, carbon footprint, and COOL programs, numerous private food-labeling systems have sprung up to provide customers with information regarding the environmental issues tied to the production of particular products. ${ }^{302}$ Consumers often are willing to pay a premium for products labeled "green," and, as such, these private foodlabeling schemes are often popular with businesses in the food sector. ${ }^{303}$ For example, the Marine Stewardship Council has created a certification program and label for seafood products derived from sustainable fisheries and seafood businesses. ${ }^{304}$ In addition, at least three food labels-Rainforest Alliance, Bird Friendly, and Fair Trade Certified-exist for coffee products. The Rainforest Alliance label ${ }^{305}$ can be found on coffee, chocolate, tea, and some fruits and certifies that the labeled

visited Dec. 5, 2013).

296. Country of Origin Labeling, U.S. DEP'T OF AGRIC., AGRIC. MARKETING SERV., http://www.ams.usda.gov/AMSv1.0/cool (last visited Oct. 26, 2013).

297. Id.

298. Czarnezki, supra note 25, at 21.

299. See Farm Security and Rural Investment Act of 2002, Pub. L. No. 107-71, 116 Stat. 134,533 (2002) (codified as amended at 7 U.S.C. $\S 1638$ (2013)).

300. See 7 C.F.R. $\$ \S 60,65$ (2013).

301. Food, Conservation, and Energy Act of 2008, Pub. L.110-234, § 11002, 122 Stat. 923, 1352-1354 (2008).

302. Czarnezki, supra note 25, at 22.

303. Id.

304. See MARINE STEWARDSHIP COUNCIL, http://www.msc.org/get-certified (last visited Oct. 26, 2013).

305. Agricultural Certification, RAINFOREST ALLIANCE, http://www.rainforestalliance.org/agriculture/certification (last visited Mar. 20, 2014). 
product was grown on a farm that supports tropical conservation by using environmentally sound agricultural practices, including integrated pest management and soil and water conservation. 306 The Smithsonian Migratory Bird Center has created the Bird Friendly label to identify organic and shade-grown coffee produced on plantations that provide desirable bird habitats. ${ }^{307}$ The Fair Trade Certified label identifies products grown by small-scale producers who are democratically organized in cooperatives or unions that use sustainable farming methods during production. ${ }^{308}$ As evidenced by the wide variety of labels certifying environmental information about food products, eco-labels have become an increasingly popular method of promoting sustainable food production by informing consumer choice.

Eco-labeling and certification schemes are certainly beneficial in affecting consumer choice, educating consumers about the environmental implications of their purchases, and influencing producers to adopt more sustainable agricultural practices. ${ }^{309}$ Despite these benefits, the organic certification and labeling programs in the United States all have one major drawback. Each program addresses certain discrete aspects of sustainable agricultural production (e.g., the prohibition on using synthetic pesticides and other synthetic substances in organic production), but none employs a whole-system approach certifying that a product was grown under a system incorporating environmental sustainability in every aspect of agricultural production. Indeed, the lack of attention given to environmental issues other than pesticide use under the United States' NOP program standards has led some smallscale organic farmers to drop out of the program or not to seek organic certification at all in an effort to "reemphasize values that have been excluded from the current meaning of organic." 310 The lack of a holistic sustainable food-labeling and

306. "Rainforest Alliance Certified" Label Search Results, Eco-labels Center, GREENERCHOICES.ORG, http://www.greenerchoices.org/eco-labels/label. cfm?LabelID=24\&searchValue= (last visited Apr. 10, 2014).

307. Shade Grown Coffee Plantations, SMITHSONIAN MIGRATORY BIRD CENTER, http://nationalzoo.si.edu/scbi/migratorybirds/coffee/default.cfm (last visited Oct. 26, 2013).

308. Label Products, FAIR TRADE USA, http://www.fairtradeusa.org/ certification/label-usage (last visited Oct. 26, 2013).

309. See Czarnezki, supra note 25, at 4; Howard \& Allen, supra note 247.

310. Howard \& Allen, supra note 247 , at 250. 
certification scheme has led to calls for a new agricultural labeling system that addresses all aspects of agricultural sustainability, including not only elimination of pesticide use, but also issues related to energy use and consumption, soil and water conservation, social and labor considerations, and promotion of biodiversity and ecosystem services. ${ }^{311}$ The system we propose in Part V of this Article attempts to do just that by building on the strengths of the whole-building approach advocated under LEED, which is discussed in detail in the next Part.

\section{LEED CERTIFICATION: WHOLE-BUILDING APPROACH}

To develop an agricultural certification system that encompasses environmental sustainability across all dimensions of food production, we need to identify an existing holistic certification system that can be used as a model to gain an understanding of how such a system would operate in the context of agriculture. To that end, this Part provides a discussion of the LEED certification program.

Developed by the United States Green Building Council (USGBC), LEED seeks to enhance the environmental sustainability of the built environment by providing standards for the identification and implementation of green building practices in the design, construction, operation, and maintenance of buildings, homes, and neighborhoods. ${ }^{312}$ Because LEED applies a holistic, whole-building approach to certifying that a building was constructed sustainably, it is an ideal program upon which to model the agricultural certification program proposed in Part V of this Article.

LEED comprises a series of rating systems that are regularly reevaluated and approved in an open and transparent public process by the nearly 13,000 USGBC

311. See Czarnezki, supra note 25, at 30 (discussing the need for a new food eco-label that would use environmental life-cycle analysis to provide consumers with information on a product's ecological footprint throughout its life cycle, from production to use and distribution). See also Howard \& Allen, supra note 247, at 250 (describing results of study indicating that consumers are interested in food eco-labels that address broader political and ethical aspects to food production, and noting the market implications of these results).

312. Overview, LEED, U.S. GREEN BLDG. COUNCIL, http://www.usgbc.org/leed (last visited Mar. 20, 2014). 
member organizations that constitute the LEED committees. ${ }^{313}$ The rating system currently in effect is LEED 2009.314 Professional individuals can become accredited for their knowledge of the LEED rating system by passing a series of exams offered by the Green Building Certification Institute (GBCI). ${ }^{315}$ The GBCI is also responsible for providing thirdparty certification for projects pursuing LEED accreditation. ${ }^{316}$ The LEED certification process provides independent, thirdparty verification that a building, home, or community was designed and constructed in accordance with the LEED standards applicable to that project. ${ }^{317}$

LEED offers a number of ratings systems that apply depending on the type of project seeking certification. ${ }^{318}$ To be eligible for LEED certification, a project must meet the following minimum characteristics: compliance with all applicable environmental laws and regulations; project permanence and completion prior to rating; use of a reasonable site boundary; compliance with minimum floor area and occupancy requirements; and commitment to sharing all available whole building energy and water use data with USGBC and/or GBCI for a period of at least five years. ${ }^{319}$

Project applicants must follow a five-step process to

313. About, LEED, U.S. GREEN BLDG. CoUNCIL, http://www.usgbc.org/about (last visited Dec. 6, 2013).

314. At the time of this writing, LEED 2009 remains in effect, although USGBC also launched the newest version of LEED, known as LEED v4, in 2013. According to USGBC, the introduction of LEED v4 will occur in phases to give the "marketplace time to become familiar with the concepts and theories that it's based on." LEED v4: the Next Version of LEED, U.S. GREEN BLDG. COUNCIL, http://www.usgbc.org/leed/v4 (last visited Oct. 29, 2013). USGBC states that it will continue to register projects under LEED 2009 until June 1, 2015. Id. For a detailed summary of LEED v4 changes from the LEED 2009 requirements for Building Design \& Construction, see LEED v4 for Building Design \& Construction, LEED, U.S. GREEN BLDG. COUNCIL, available at http:/I www.usgbc.org/sites/default/files/Summary\%20of\%20Changes\%20-\%20LEED\% 202009\%20to\%20LEED\%20v4\%20-\%20BD+C.pdf.

315. LEED Professional Credentials, LEED, U.S. GREEN BLDG. CoUnCIL, https://usgbc.org/leed/credentials (last visited Dec. 5, 2013).

316. About GBCI, GREEN BLDG. CERTIFICATION INST., http://www. gbci.org/orgnav/about-gbci/about-gbci.aspx (last visited Mar. 20, 2014).

317. LEED, U.S. GREEN BLDG. CouNCIL, https://usgbc.org/leed llast visited Mar. 20, 2014).

318. LEED Rating Systems, LEED, U.S. GREEN BLDG. COUNCIL, https://usgbc.org/leed/rating-systems (last visited Dec. 5, 2013).

319. Minimum Program Requirements, LEED, U.S. GREEN BLDG. COUNCIL (2011), http://www.usgbc.org/Docs/Archive/General/Docs6715.pdf. 
achieve LEED certification. ${ }^{320}$ First, applicants must identify the appropriate rating system for the project and prepare a certification application in accordance with the guidelines specified under the appropriate system. ${ }^{321}$ Second, applicants pay a registration fee ( $\$ 900$ for USGBC members or $\$ 1,200$ for non-members) to register the project for certification. ${ }^{322}$ Third, applicants submit a certification application and pay a certification review fee, the amount of which depends on the type and size of the project. ${ }^{323}$ Fourth, applicants must wait for a review of the application. Finally, applicants receive the certification decision, which each applicant can either accept, which means the project is officially LEED certified, or, if certification was not granted, appeal. ${ }^{324}$

A project achieves LEED certification by earning points that are allocated to credit-requirement categories across the different rating systems. ${ }^{325}$ Points are weighted based on their relative effectiveness in reducing environmental problems, as defined under USGBC program goals. ${ }^{326}$ To assign points' relative weight, LEED 2009 uses the environmental impact categories set forth in the EPA's Tools for the Reduction and Assessment of Chemical and Other Environmental Impacts (TRACI), which are widely used to evaluate materials in the conduction of Life Cycle Assessments. ${ }^{327}$ Under the new version of LEED (LEED v4) however, the USGBC will weight points using a new set of impact categories developed specifically for LEED $v 4$ to address the USGBC organization's mission and

320. How to Certify a Building Project, LEED, U.S. GREEN BLDG. COUNCIL, https://usgbc.org/leed/certification (last visited Dec. 5, 2013).

321. Choose Your Rating System, Certification, LEED, U.S. GREEN BLDG. Councll, http://www.usgbc.org/leed/certification/choose (last visited Oct. 29, 2013).

322. Register Your Project, Certification, LEED, U.S. GREEN BLDG. COUNCIL, http://www.usgbc.org/leed/certification/register (last visited Oct. 29, 2013).

323. Submit Your Application, Certification, LEED, U.S. GREEN BLDG. CouncIL, http://www.usgbc.org/leed/certification/submit (last visited Oct. 29, 2013).

324. Certify, Certification, LEED, U.S. GREEN BLDG. COUNCIL, http://www.usgbc.org/leed/certification/certify (last visited Oct. 29, 2013).

325. BRENDAN OWENS ET AL., U.S. GREEN BLDG. COUNCIL, LEED V4 IMPACT CATEgory AND POINT ALlOCATION DEvelopment PROCESS at 2, available at http://www.usgbc.org/resources/leed-v4-impact-category-and-point-allocationprocess-overview (last visited Feb. 14, 2014).

326. Id.

327. Id. 
overall goals for the LEED program. ${ }^{328}$ The impact categories used under the LEED v4 weightings system seek to address seven overarching program goals: (1) reduce contribution to global climate change; (2) enhance individual human health and well-being; (3) protect and restore water resources; (4) protect, enhance, and restore biodiversity and ecosystem services; (5) promote sustainable and regenerative material resource cycles; (6) build a greener economy; and (7) enhance social equity, environmental justice, and community quality of life. ${ }^{329}$ This new weightings system assigns more points to credits that significantly contribute to accomplishing these system goals. ${ }^{330}$

To become certified under LEED 2009, a commercial building or neighborhood must earn at least forty points out of one hundred possible points on the applicable rating system scale. ${ }^{331}$ Homes must achieve a minimum of forty-five points on a one hundred point LEED rating system scale. ${ }^{332}$ These points are allocated over five major credit categories: (1) sustainable site development, (2) water efficiency, (3) energy efficiency, (4) materials selection, and (5) indoor environmental quality. ${ }^{333}$ Three additional credit categories are available for Neighborhood Development, including smart location and linkage, neighborhood pattern and design, and green infrastructure and buildings. ${ }^{334}$ Two additional credit categories are also available for homes: location and linkage, and awareness and education. ${ }^{335}$ Ten bonus points are available for projects meeting the standards set forth in the Innovation in Design or Regional Priority credit categories. ${ }^{336}$ Each credit category contains a collection of mandatory and

328. Id. at 4. Owens et al. state that this departure from the LEED 2009 weightings system came about because the TRACI categories used under LEED 2009 were designed to evaluate the sustainability of individual materials, not whole buildings. The TRACI categories therefore do not capture a comprehensive picture of a building's sustainability. Accordingly, USGBC developed the new set of impact categories and goals for LEED $\mathrm{v} 4$ in an effort to specifically address sustainability issues related to all aspects of the built environment. Id. at 2 .

329. Id.

330. Id.

331. Certify, U.S. GREEN BLDG. CouncIL, supra note 324.

332. Id.

333. LEED Rating Systems, U.S. GREEN BLDG. CoUNCIL, supra note 318.

334. Id.

335. Id.

336. Id. 
optional strategies that can be employed to earn points under that category. ${ }^{337}$ Depending on the number of points achieved, a project will qualify for one of four levels of certification: Certified (forty to forty-nine points), Silver (fifty to fifty-nine points), Gold (sixty to seventy-nine points), or Platinum (eighty points and above). ${ }^{338}$

\section{LEED 2009 Credit Example Strategies Category}

\begin{tabular}{|c|c|}
\hline Sustainable Sites & $\begin{array}{ll}\text { - } & \text { Infill development } \\
\text { - } & \text { Minimized impacts to surrounding } \\
\text { ecosystems } \\
\text { - Regional landscaping } \\
\text { - Reduction of construction-related } \\
\text { pollution }\end{array}$ \\
\hline Water Efficiency & $\begin{array}{l}\text { - Efficient appliances and fixtures } \\
\text { - Water-conscious landscaping }\end{array}$ \\
\hline $\begin{array}{l}\text { Energy \& } \\
\text { Atmosphere }\end{array}$ & $\begin{array}{ll}\text { - } & \text { Energy-use monitoring } \\
\text { - Energy efficient design and construction } \\
\text { - Efficient appliances, systems, and } \\
\text { lighting } \\
\text { - Use of renewable and clean sources of } \\
\text { energy }\end{array}$ \\
\hline $\begin{array}{l}\text { Materials \& } \\
\text { Resources }\end{array}$ & $\begin{array}{l}\text { - Selection of sustainably derived } \\
\text { materials } \\
\text { - Waste reduction, reuse, and recycling }\end{array}$ \\
\hline $\begin{array}{l}\text { Indoor } \\
\text { Environmental } \\
\text { Quality } \\
\end{array}$ & $\begin{array}{l}\text { - Improved indoor air quality } \\
\text { - Access to natural daylight and views } \\
\text { - Improved acoustics }\end{array}$ \\
\hline \multicolumn{2}{|c|}{ Additional Credit Categories for Neighborhood Development } \\
\hline Location \& Linkage & $\begin{array}{l}\text { - Proximity to open spaces, infrastructure, } \\
\text { and efficient transit }\end{array}$ \\
\hline $\begin{array}{l}\text { Neighborhood } \\
\text { Pattern \& Design }\end{array}$ & $\begin{array}{l}\text { - Mixed-use neighborhood development } \\
\text { - Walkability }\end{array}$ \\
\hline
\end{tabular}

337. OWENS ET AL., supra note 325, at 3. Mandatory strategies are considered "prerequisites," while optional strategies are known as "credits." A project must demonstrate documented compliance with all prerequisites and earn a sufficient number of credit requirements to achieve certification. Id.

338. Certify, U.S. GREEN BLDG. COUNCIL, supra note 324. 


\begin{tabular}{lll}
\hline & $\bullet$ & Connections to nearby communities \\
\hline Green Infrastructure & $\bullet$ & $\begin{array}{l}\text { Reduced environmental consequences of } \\
\text { building and infrastructure construction } \\
\text { \& Building }\end{array}$ \\
& and operation \\
\hline
\end{tabular}

Additional Credit Categories for Homes

\begin{tabular}{|c|c|}
\hline Location \& Linkage & $\begin{array}{l}\text { - Construction on previously developed } \\
\text { and infill sites } \\
\text { - Walkability } \\
\text { - Access to efficient transportation and } \\
\text { open space }\end{array}$ \\
\hline $\begin{array}{l}\text { Awareness \& } \\
\text { Education }\end{array}$ & $\begin{array}{l}\text { - Education and tools regarding ownership } \\
\text { of green home }\end{array}$ \\
\hline \multicolumn{2}{|r|}{ Bonus Categories } \\
\hline Innovation \& Design & $\begin{array}{l}\text { - Outstanding performance through } \\
\text { innovative technologies or strategies } \\
\text { - Green building strategies not specifically } \\
\text { addressed elsewhere in LEED } \\
\text { - LEED Accredited Professional on project } \\
\text { design team }\end{array}$ \\
\hline Regional Priority & $\begin{array}{l}\text { Strategies address specified local } \\
\text { environmental concerns }\end{array}$ \\
\hline
\end{tabular}

Table 1. LEED 2009 credit categories for home construction projects with example strategies for achieving points in each category

The LEED 2009 certification system encourages a wholebuilding life-cycle approach to environmental sustainability by recognizing achievement in key impact categories affecting human and environmental health and awarding points for performance across the five major and any other applicable credit categories. ${ }^{339}$ Credits available under the Sustainable Sites category "encourage strategies that minimize the impact on ecosystems and water resources." 340 This category evaluates factors related to the project site selection and development by discouraging development on previously undeveloped land; rewarding minimization of project impacts on ecosystems and

339. LEED Rating Systems, U.S. GREEN BLDG. COUNCIL, supra note 318.

340. Id. 
waterways; encouraging implementation of appropriate storm water controls and regionally appropriate landscaping; and promoting reduction of erosion, light pollution, heat island effects, and construction-related pollution. 341 The Water Efficiency credits "promote smarter use of water, inside and out, to reduce potable water consumption." 342 This category encourages smart use of water by awarding points for the use of efficient appliances, fixtures, fittings, and water-conscious landscaping. ${ }^{343}$ The Energy \& Atmosphere credits "promote better building energy performance through innovative strategies" by encouraging a variety of energy efficient strategies, including commissioning; energy-use monitoring; efficient design and construction; use of efficient appliances, systems, and lighting; and use of renewable and clean sources of energy. 344 Credits available under the Materials \& Resources category "encourage using sustainable building materials and reducing waste." 345 This category promotes the selection of sustainably grown, harvested, produced, and transported products and encourages waste reduction, reuse, and recycling. ${ }^{346}$ The Indoor Environmental Quality category promotes strategies that improve indoor air, provide access to natural daylight and views, and improve acoustics. ${ }^{347}$

Additional credit categories that apply only to neighborhood development projects include Smart Location \& Linkage credits, Neighborhood Pattern \& Design credits, and Green Infrastructure \& Buildings credits. ${ }^{348}$ The Smart Location \& Linkage category encourages the development of neighborhoods that are walkable with access to open spaces and efficient transportation options. ${ }^{349}$ The Neighborhood Pattern \& Design credit category awards points for mixed-use neighborhoods designed to be compact and walkable communities that offer good connectivity to nearby communities. ${ }^{350}$ Finally, the Green Infrastructure \& Buildings

\footnotetext{
341. See id.

342. Id.

343. See id.

344. See id.

345. Id.

346. Id.

347. Id.

348. Id.

349. Id.

350. Id.
} 
category awards points for strategies that minimize environmental impacts from construction and operation of buildings and neighborhood infrastructure. 351

Two categories apply only to the construction of homes: the Locations \& Linkages category rewards homes built near open space, already-existing infrastructure, and transit, while the Awareness \& Education category encourages home builders and real estate professionals to provide homeowners, tenants, and building managers with education and tools needed to understand how to make the most of their green home. ${ }^{352}$

LEED 2009 offers two categories under which up to ten bonus points may be awarded for the use of innovative or regionally specific strategies. Up to six bonus points can be awarded under the Innovation \& Design category for projects that use innovative technologies or strategies to improve performance well beyond what is required by other LEED credits, to account for green building considerations that are not specifically addressed elsewhere in LEED, or for projects that include a LEED Accredited Professional on the design team. ${ }^{353}$ Finally, up to four bonus points may be awarded under the Regional Priority category for projects that encompass strategies for addressing specified local environmental concerns (as established by USGBC regional institutions). ${ }^{354}$

In an effort to encourage the adoption of green building design, construction, and operations practices, many state and local governments have begun to require green building or offer targeted financial and structural incentives that reward developers and homeowners for achieving LEED certification. ${ }^{355}$ A number of state and local governments have created financial incentives, such as tax credits and exemptions

351. Id.

352. Id.

353. Id.

354. Id.

355. Aaron P. Silberman, Green Building: Federal, State, and Local Governments LEED the Way, 43 SPG PROCUREMENT LAW. 7, 7 (2008); Alexandra B. Klass, State Standards for Nationwide Products Revisited: Federalism, Green Building Codes, and Appliance Efficiency Standards, 34 HARV. ENVTL. L. REV. $335,342(2010)$. For a detailed description of green building incentive initiatives in the United States, see USGBC: Green Building Incentive Strategies, U.S. GREEN BLDG. COUNCIL, available at http://www.usgbc.org/Docs/Archive/ General/Docs6248.pdf. 
for homes and developments that achieve measurable green building goals under LEED. ${ }^{356}$ The state of New Mexico, for example, has enacted legislation providing sustainablebuilding tax credits based on square footage for commercial and residential buildings that achieve specified levels of LEED certification. .357

Structural incentives such as density bonuses ${ }^{358}$ and expedited permitting and review processes have also become popular among local and state governments, as such structural incentives often involve only simple modifications to zoning procedures and can thus be achieved at little or no cost to local governments. ${ }^{359}$ Examples of such structural-incentive initiatives can be found in many states, including Hawaii, where a state law directs counties to establish expedited permitting procedures for green building projects, ${ }^{360}$ and in municipalities such as Gainesville, Florida, where a city ordinance offers a fast-track building permit procedure and reduction in building permit fees for private contractors using LEED. ${ }^{361}$

Moreover, many states, including California, Connecticut, and Washington, now require all new state construction to meet LEED criteria, and a large number of local governments, including New York City, Boston, and Chicago, now mandate that municipal government buildings be constructed in accordance with green building specifications. ${ }^{362}$ While a number of problems associated with the incorporation of LEED standards into state and local government law have been identified, ${ }^{363}$ including the question of whether state and local laws should be based on standards which, like LEED, are set

356. USGBC: Green Building Incentive Strategies, U.S. GREEN BLDG. CoUNCIL, supra note 355 .

357. N.M. STAT. ANN. § 7-2-18.19 (2009).

358. A density bonus, an incentive zoning technique, is a land use tool that allows developers to increase the maximum development permitted on a property in exchange for conferring some public benefit. See John R. Nolon, Zoning and Land Use Planning, 36 REAL EST. L. J. 350, 369 (2007).

359. USGBC: Green Building Incentive Strategies, U.S. GREEN BLDG. COUNCIL, supra note 356 .

360. HAW. REV. STAT. § 46-19.6 (2006).

361. GAINESVILle, FLA., CODE ch. 6, art. I.5, $\S \S 6-5$ to 6-15 (2012).

362. Klass, supra note 365, at 343-44.

363. Michael Allan Wolf, A Yellow Light for "Green Zoning": Some Words of Caution About Incorporating Green Building Standards into Local Land Use Law, 43 URB. LAW. 949, 957 (2011). 
by private parties and designed to evolve over time, ${ }^{364}$ local and state governments continue to promote green building practices through the incorporation of financial and structural incentives into laws and regulations. Encouraging green building practices has become so desirable, in fact, that as of 2009 LEED-incentive initiatives existed in at least forty-five states, two hundred and six local governments, fourteen federal agencies or departments, and forty-one higher education institutions across the United States. ${ }^{365}$ According to the Green Building Council, more than 54,000 projects are participating in the LEED program to date. 366

Strengths of the LEED program include its flexible credit system, the transparent nature of the standards-setting process, and the program's whole-building life-cycle approach to certification. Because LEED credits are awarded for reducing a building's overall environmental impact rather than for meeting a list of specific criteria, the credit-rating systems provide flexibility in the design and construction process by allowing a project's design team to choose which points to pursue. ${ }^{367}$ LEED standards are regularly re-evaluated through a process wherein member organizations develop and approve program standards by consensus, a strength that ensures that no stakeholder groups are given special weight or excluded. 368 Another program strength thus lies in the USGBC's ability to revise the LEED standards in response to changing conditions and new information. Finally, LEED's whole-building life-cycle approach is considered to be valuable, as the holistic nature of the certification process requires a project's entire design team to focus on addressing specific environmental and energy considerations in the early stages of the design process. ${ }^{369}$

Despite the program's strengths, LEED has also been criticized for its high implementation costs, insensitivity to regional differences, and lack of performance measurement and

364. Id.

365. LEED Public Policies, U.S. GREen BlDG. CouncIl, 1 (May 2010), available at http:/www.usgbc.org/Docs/Archive/General/Docs691.pdf.

366. About, U.S. GREEN BLDG. COUNCIL, supra note 313.

367. Julie Cidell, A Political Ecology of the Built Environment: LEED Certification for Green Buildings, 14 LOC. ENV'T 621, 622 (2009).

368. About, U.S. GREEN BLDG. COUNCIL, supra note 313.

369. Building Green in Pennsylvania, GOVERNOR's GREEN GOV'T COUNCIL, U.S. ENVTL. PROT. AGENCY, 2, http://www.epa.gov/statelocalclimate/documents/ pdf/ 12_8_what_is_green_GGGC.pdf (last visited Mar. 6, 2014). 
monitoring considerations. ${ }^{370}$ Critics point out that the high costs associated with the design, construction, and certification of a LEED-certified building can place green buildings out of the economic reach of low-income populations, ${ }^{371}$ and some have argued that, by forgoing certification, a developer could instead use the certification funds to invest in strategies to make the project even more sustainable. ${ }^{372}$ While the initial costs of design and construction of a LEED-certified building are typically higher than those of non-LEED buildings, many of these costs are often offset over time by savings due to higher building efficiency and resulting lower operational costs. 373 LEED is also often criticized for containing credit categories that are insensitive to regional climatic and environmental differences, such that a building in Maine can receive the same credit for water conservation as a building in Arizona despite the fact that water scarcity is a far more critical issue in the latter area. ${ }^{374}$ The USGBC has attempted to address this criticism with the inclusion of the bonus Regional Priority credit category in the 2009 LEED standards ${ }^{375}$ and will likely continue to revise the LEED standards in coming years to address this, and similar, issues. Another criticism of LEED is that the program acts simply as a design tool, not a performance-measurement tool, because it lacks a mechanism for monitoring a project's environmental performance over time. ${ }^{376}$ As such, a project can achieve LEED certification by earning credits for the use of environmentally friendly strategies articulated in the rating systems, but because the project's performance is not monitored, there is no guarantee that the project will continue to maintain these environmental

370. See Cidell, supra note 367, at 629. See also Scott Wick, LEED: The Good, Bad, and Ugly, OHIO REAL EsT. BLOG (July 16, 2009, 9:00 AM), http:/www. ohiorelaw.com/2009/07/leed-good-bad-and-ugly.html.

371. Cidell, supra note 367, at 629.

372. Wick, supra note 370.

373. Eileen D. Millet, Green Building for Dummies: What is a LEED Certification?, 25 PRAC. REAL EST. LAW. 41, 47 (2009).

374. JOHN P. LAMB, THE GREENING OF IT: HOW COMPANIES CAN MAKE A DIFFERENCE FOR THE ENVIRONMENT 119 (2009).

375. Ellen Honigstock, LEED Regional Priority Credits, URBAN GreEN COUNCIL BLOG (Feb. 8, 2012), http://blog.urbangreencouncil.org/2012/02/leedregional-priority-credits/.

376. Vanessa Quirk, Where is LEED Leading Us?. . And Should We Follow?, ARCH DAILY (Apr. 23, 2012), http://www.archdaily.com/227934/where-is-leedleading-us-and-should-we-follow. 
benefits after completion. ${ }^{377}$

The LEED program standards have become the established benchmark for the certification of green buildings both across the United States and in many other countries. 378 LEED has been hailed as a "potent weapon in the growing arsenal of practices designed to lessen impact on the environment, reduce conspicuous consumption, and utilize existing, or new and improved, materials to equal effect."379 LEED's success has been based in part on its "whole-building" approach, which seeks to achieve sustainability in the built environment by considering all aspects of a building's environmental footprint instead of attempting to address sustainability and environmental efficiency through small or piecemeal strategies. ${ }^{380}$ The next Part draws on LEED's holistic, integrated approach to green building sustainability to propose a similar system for agricultural sustainability certification.

\section{From "Whole-Building" TO "WhOLE-SYSTEM": USING LEED AS A MODEL FOR CERTIFYING AGRICULTURAL RESILIENCE}

If we seek to increase our ability to continue to meet the worldwide demand for food despite the predicted impacts of climate change, it will become necessary to radically transform our agricultural system away from industrialization toward a more resilient, ecologically conscious system of production. One potential way to encourage such a massive shift in attitude and practice could be by implementing a "whole-system" program of agricultural certification that rewards agricultural practices that increase resilience across all components of the farm ecosystem. The "whole-building" certification approach applied under the LEED green building certification program offers insights into the potential design and implementation of a whole-system agricultural certification program.

Drawing on the strengths of the LEED program, a wholesystem agricultural certification program would seek to enhance the environmental sustainability of agriculture by

377. Id.

378. Cidell, supra note 367 , at 621.

379. Millet, supra note 373 , at 42.

380. GOVERNOR'S GREEN GOV'T COUNCIL, supra note 369. 
providing standards for ecologically-sound farming practices that farmers would be required to achieve in order to become certified. These standards would be based on the goal of increasing resilience through the use of agricultural practices that increase biodiversity and ecosystem service provision by emphasizing the health and function of all components of a farm ecosystem, similar to the way that the LEED standards encourage environmental sustainability in the built environment. The LEED standards are developed, approved, and regularly re-evaluated by USGBC member organizations. ${ }^{381}$ A similar process for development and review of standards could be developed under the proposed agricultural certification program. This would obviously require oversight by an implementing organization similar to the USGBC, comprising various agricultural, environmental, or policy member organizations that would assist in developing and regularly re-evaluating the program standards. The implementing organization would also be responsible for establishing an affiliate organization analogous to the Green Building Certification Institute (GBCI) under LEED, which would provide third-party certification for farms pursuing certification under the proposed program. Certification would therefore represent independent, third-party verification that a farm or agricultural system produces agricultural products in accordance with applicable program standards.

To obtain certification under the proposed program, a farmer would submit an application to the implementing organization documenting a farm's compliance with the requirements set forth in the applicable rating system. Similar to the prerequisites that must be met before a construction project can apply for certification under LEED, a farm seeking certification would be required to meet established prerequisites. These prerequisites could address such issues as compliance with all applicable environmental laws and regulations, land tenure status of the farm, or commitment to sharing specified data with the implementing organization for a specified length of time after certification.

After applying for certification under the proposed program, the certification body of the implementing

381. Developing LEED, About, U.S. GREEN BLDG. COUNCIL, http://www.usgbc. org/about/leed (last visited Dec. 5, 2013). 
organization would evaluate participating farms for their overall resilience based on the program standards and credit categories. Points would be awarded across multiple credit categories, with each category addressing discrete aspects of agricultural resilience. Under LEED $\mathrm{v} 4$, credits will be weighted based on a set of impact categories developed to address the USGBC organization's mission and overall goals for the LEED program, ${ }^{382}$ while previous iterations of LEED used environmental impact categories generated by federal environmental agencies to assign weight to credits. ${ }^{383}$ Under the proposed agricultural certification program, the certifying organization could develop its own impact categories using the LEED v4 weighting method as a model. In the alternative, drawing on the weighting method previously employed under LEED 2009, federal environmental impact categories or other government environmental impact standards specifically related to agriculture could form the basis for weighting credits. ${ }^{384}$ Under either method, the credit weighting process could be modeled after that of LEED: first, the farm's environmental impacts would be estimated using established scientific methodology; second, the relative importance of the estimated impacts would be evaluated using either program or federal criteria; and third, points would be assigned using data quantifying the farm's impacts on ecosystem, landscape, and human health.

The proposed program would encourage a whole-system approach to agricultural certification by recognizing achievement in key areas related to a farm's overall resilience. Points would therefore be awarded for performance across categories capturing different aspects of agricultural resilience and sustainability. Possible categories would therefore encompass all aspects of agricultural resilience, including biodiversity and ecosystem services protection, water and soil conservation, and use of sustainable materials and responsible production/disposal of wastes, as well as categories related to landscape and social considerations. The following table provides possible categories under which points could be awarded, with example farming techniques or strategies given

382. OWENS ET AL., supra note 325 , at 4.

383. Id.

384. Id. at 2. 
for each category. Each category is then discussed in more detail below.

\begin{tabular}{|c|c|c|}
\hline $\begin{array}{l}\text { Agricultural } \\
\text { Certification } \\
\text { Category }\end{array}$ & Example Strategies & $\begin{array}{l}\text { Analogous } \\
\text { LEED } \\
\text { Category }\end{array}$ \\
\hline $\begin{array}{l}\text { Sustainable } \\
\text { Sites }\end{array}$ & $\begin{array}{l}\text { - Appropriate crop for geographic } \\
\text { location } \\
\text { - Appropriate crop variety for } \\
\text { disease and pest resistance } \\
\text { - Appropriate crop for available } \\
\text { water supply } \\
\text { - Not highly erodible land } \\
\text { - Not wetlands } \\
\text { - Not other environmentally } \\
\text { sensitive lands (e.g., threatened } \\
\text { or endangered species not } \\
\text { present) }\end{array}$ & $\begin{array}{l}\text { Sustainable } \\
\text { Sites }\end{array}$ \\
\hline $\begin{array}{l}\text { Biodiversity } \\
\text { Protection }\end{array}$ & $\begin{array}{l}\text { - Integrated pest management } \\
\text { - Intercropping } \\
\text { - } \text { Maintenance of refugia } \\
\text { - Non-use of genetically modified } \\
\text { organisms } \\
\text { - } \begin{array}{l}\text { Environmentally sound use and } \\
\text { management of biotechnology } \\
\text { - Prevention of disease } \\
\text { - Non-use and control of exotic } \\
\text { species }\end{array} \\
\end{array}$ & $\begin{array}{l}\text { No } \\
\text { Analogue }\end{array}$ \\
\hline $\begin{array}{l}\text { Soil \& Water } \\
\text { Conservation }\end{array}$ & $\begin{array}{ll} & \text { Erosion reduction practices } \\
\text { - } & \text { Enrichment of soils } \\
\text { - } & \text { Reduction of pollution } \\
\text { - } & \text { Limitation of runoff } \\
\end{array}$ & $\begin{array}{l}\text { Water } \\
\text { Efficiency }\end{array}$ \\
\hline $\begin{array}{l}\text { Sustainable } \\
\text { Materials \& } \\
\text { Resources }\end{array}$ & $\begin{array}{ll}\text { - Selection of sustainably and } \\
\text { locally derived materials } \\
\text { - Use of renewable and clean } \\
\text { sources of energy } \\
\text { - } \\
\text { Efficient natural resources use } \\
\text { Reduced reliance on heavy farm } \\
\text { equipment }\end{array}$ & $\begin{array}{l}\text { Materials \& } \\
\text { Resources, } \\
\text { Energy \& } \\
\text { Atmosphere }\end{array}$ \\
\hline
\end{tabular}




\begin{tabular}{|c|c|c|}
\hline & $\begin{array}{ll}\text { - } & \text { Reduced fossil fuel use } \\
\text { - } & \text { Reduced food miles traveled } \\
\text { - } & \text { Waste reduction, reuse, and } \\
& \text { recycling } \\
\text { - } & \text { Reduced GHG and nitrogen } \\
\text { emissions }\end{array}$ & \\
\hline $\begin{array}{l}\text { Landscape \& } \\
\text { Location }\end{array}$ & $\begin{array}{l}\text { Farm location (e.g., minimized } \\
\text { conversion of open spaces/ } \\
\text { natural areas) } \\
\text { - } \text { Maintenance of biological } \\
\text { corridors } \\
\text { - } \text { Prevention of off-farm pollution } \\
\text { - } \text { Conservation of native habitats } \\
\text { Conservation of important } \\
\text { species using targeted strategies } \\
\text { Prevention of habitat } \\
\text { fragmentation } \\
\text { Local/regional distribution } \\
\text { system }\end{array}$ & $\begin{array}{l}\text { Locations \& } \\
\text { Linkages }\end{array}$ \\
\hline Social \& Labor & 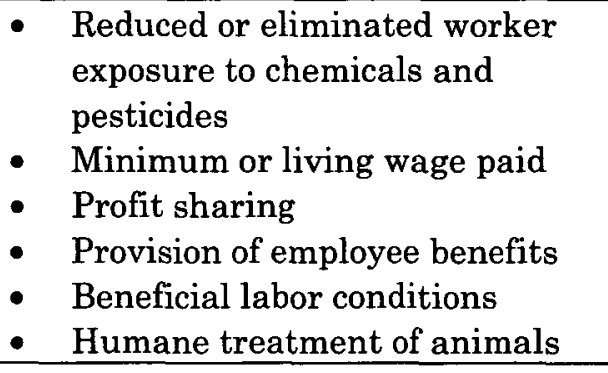 & $\begin{array}{l}\text { No } \\
\text { Analogue }\end{array}$ \\
\hline $\begin{array}{l}\text { Innovation \& } \\
\text { Design (bonus } \\
\text { category) }\end{array}$ & $\begin{array}{l}\text { Outstanding performance } \\
\text { through innovative technologies } \\
\text { or strategies } \\
\text { - Resilience building strategies } \\
\text { not specifically addressed } \\
\text { elsewhere }\end{array}$ & $\begin{array}{l}\text { Innovation } \\
\text { \& Design } \\
\text { (bonus } \\
\text { category) }\end{array}$ \\
\hline $\begin{array}{l}\text { Regional } \\
\text { Priority (bonus } \\
\text { category) }\end{array}$ & $\begin{array}{l}\text { Strategies address specified } \\
\text { local environmental concerns }\end{array}$ & $\begin{array}{l}\text { Regional } \\
\text { Priority } \\
\text { (bonus } \\
\text { category) }\end{array}$ \\
\hline
\end{tabular}

Table 2. Potential agricultural certification program categories, with example strategies for achieving points in each category and analogous LEED 2009 category 
This proposed certification program would encourage a whole-system approach to agricultural production by recognizing achievement in key categories affecting agricultural resilience and sustainability and awarding points for performance across the categories. Under the Sustainable Sites category, points would be awarded for choosing appropriate crops and crop varieties for the particular site. This would encourage the use of crop varieties that are appropriate for the climatic and geographic characteristics of the site. For example, farmers who choose to plant crops that require substantial irrigation in an arid region would not receive points. Similarly, points would not be awarded to farms growing varieties that are very susceptible to particular pests prevalent in that region, therefore requiring the application of large quantities of synthetic pesticides, or to farmers planting crops that require highly toxic pesticides in regions in which endangered species vulnerable to those pesticides are present.

Under the Biodiversity Protection category, points would be awarded for practices that increase or protect biodiversity and ecosystem services, both of which contribute to the resilience of the system. Such practices would include the use of integrated pest management, intercropping, maintenance of refugia, habitat preservation, non-use of genetically modified organisms, environmentally sound use and management of biotechnology, prevention of disease, and non-use and control of exotic species.

Under the Soil \& Water Conservation category, farms would receive points for practices that protect the health of soil and water resources, which would include such activities as limiting erosion, enriching soils, reducing pollution, conserving water, and limiting runoff.

Points could be awarded under the Sustainable Materials \& Resources category for strategies that promote energy efficiency, the use of sustainable input materials, and sustainable production and disposal of wastes. Strategies for earning points under this category for energy efficiency could include use of renewable resources, reduced reliance on synthetic pesticides and fertilizers, reduced use of fossil fuels to operate farm machinery and to transport goods, and the use of locally derived inputs. Strategies that could be employed to earn points for sustainable production and disposal of wastes could include reduction in GHG and nitrogen emissions, 
minimization and recycling of wastes, and proper handling and disposal of wastes.

The Landscape \& Location category could award points for factors related to farm location within the larger landscape. Points could be awarded under this category for farms situated in desirable locations, such as near already urbanized areas, which would serve the dual purpose of reducing food miles traveled and reducing clearing of ecologically intact areas for conversion to farmland. Points could also be awarded for practices that increase the overall health of the landscape surrounding the farm, including maintenance of biological corridors, non-conversion of natural areas for agriculture, prevention of off-farm pollution, conservation of native habitats, conservation of important species through targeted strategies, and prevention of habitat fragmentation.

Points could be awarded under the Social \& Labor category for practices that sustain farmworker health and livelihoods. These practices could include reduced or eliminated worker exposure to chemicals and pesticides, payment of minimum wage or a living wage, sharing of profits with farm employees, provision of employee benefits, humane treatment of animals, and overall beneficial labor conditions.

Finally, under the Innovation \& Design category, bonus points could be awarded for farms using innovative technologies or practices, or to account for resilience strategies not specifically addressed within the other program categories. Bonus points could also be awarded for strategies addressing specific local environmental concerns, as under LEED's Regional Priority category. These regional concerns would need to be identified by the implementing entity's regional member organizations and could encompass such regional considerations as efficient use of water in dry areas where water resource availability is limited or compliance above and beyond what is required by local environmental laws.

The key to making certification a desirable achievement for farmers is linking certification to consumer purchasing. Under this proposal, farms that receive sufficient credits to obtain certification would be able to label and advertise their products as coming from a certified operation. Informed consumers desiring food that is grown in a sustainable and ecologically resilient manner may be willing to switch their purchasing preferences to products labeled as coming from 
certified operations. Moreover, as has occurred with the existing NOP, ${ }^{385}$ many consumers may be willing to pay a premium for such products. If farmers who become certified are able to gain market share or capture premium prices, wholesystem certification could become a much sought after goal in the agricultural industry.

There are, of course, additional considerations that would need to be addressed for the proposed whole-system agricultural certification program to be most effective. The first is perhaps the most obvious: an institution responsible for implementing the program, developing the standards, and certifying individual farms for resilience must be identified. A new organization responsible for administering the proposed program, modeled after the USGBC, could be created. The program could also be administered through an existing institution or framework, such as the United States' organic certification infrastructure administered through the NOP. The entity responsible for administering the proposed certification program, whether it is an existing entity or a newly created one, must be flexible in developing standards and operating the program. As discussed in Part IV, one of LEED's strengths is that it is administered by the USGBC, an independent, thirdparty organization comprised of thousands of member organizations interested in green building certification. 386 The independent nature of USGBC gives LEED program flexibility, in that development of standards and the actual certification process are achieved by USGBC members through an open and transparent process without the bureaucracy and red tape that is often associated with government involvement. The proposed program may benefit from an organizational structure similar to the third-party implementing structure that affords LEED such flexibility.

Another issue that merits consideration relates to one of the major criticisms of LEED: that the program categories do not effectively address regional environmental differences, aside from the potential award of bonus points for strategies that address specific local environmental concerns. ${ }^{387}$ Regional differences in environmental concerns, such as water

385. See Constance \& Choi, supra note 248.

386. About, U.S. GREEN BLDG. COUNCIL, supra note 313.

387. LAMB, supra note 374 . 
availability, pollution issues, presence of environmentally sensitive ecosystems or threatened or endangered species, and differing state and local government environmental laws and regulations could impact an individual farm's ability to achieve program standards. Though the proposed program attempts to address regional variation through the award of bonus points, the importance of considering regional differences in developing meaningful program standards might dictate that the program design be structured in a way to reflect sensitivity to this issue.

Of course, the whole-system certification approach set forth in this Article is primarily geared toward consumers in the developed world. Only relatively wealthy consumers are likely to be willing to seek out-and perhaps pay more forfood that is grown in an ecologically resilient manner. Thus, whole-system certification may only influence the purchasing habits of consumers in the United States, Europe, and other wealthy regions, and is unlikely to influence decisions made by consumers in poorer regions of the developing world, who often lack the financial resources to consider paying a higher price for sustainable food. Nevertheless, such an approach could have indirect global implications. For example, the wholesystem approach could lead to more research and development on ecologically resilient agricultural practices, which could be exported to developing countries which may not have the resources to grow in fossil fuel-intensive ways, but which nonetheless are seeking to improve yields and long-term sustainability. If farmers in the developing world put these practices in place, not only will there be environmental improvements and agricultural systems that are more adaptable to the potential significant impacts of climate change, but in addition, food security in the developed world could be dramatically improved. By growing crops in ways that make them less susceptible to the droughts, increases in temperature, increases in disease, and pest outbreaks that are likely to occur, farmers will be better able to continue to produce crops even under times of stress or disturbance caused by climate change. Accordingly, farmers and the communities they serve in the developing world will have more secure food sources.

In addition, much of the developing world currently imports a relatively large proportion of grain from the United 
States and other developed countries, and it is likely that such imports will continue in the future. ${ }^{388}$ Thus, if farmers in the United States successfully adopt the whole-system approach, even certified products intended for developing countries would be grown in an ecologically-resilient manner. Even more significant, however, switching to a more ecologically-resilient form of agriculture will result in substantial decreases in global GHG emissions by reducing the use of fossil fuel intensive pesticides, fertilizers, and transportation. This reduction in GHG emissions will help, at least to some extent, to mitigate the adverse impacts of climate change.

\section{PUTTING The LEED APPROACH INTO PRACTICE}

Perhaps the greatest challenge in establishing a wholesystem agricultural certification program is how to convince farmers to participate in the program. It is not clear whetheror to what extent-farmers would be interested in voluntarily participating in this type of whole-system certification program, though a number of potential options exist for encouraging their participation. It should be noted that voluntary participation in the LEED program has been robust, a testament to the fact that developers benefit from participating in LEED to such an extent that program participation continues to grow. ${ }^{389}$ Similarly, some of the benefits of a LEED-type approach that currently accrue to developers would translate to farmers participating in the whole-system certification program. For example, energy efficiency and reduced reliance on costly pesticides and fertilizers could be desirable in that they reduce the costs of farming. However, a farmer's reasons for planting certain crops and using particular practices are extremely complex. Market forces, government subsidy programs such as those provided in the Farm Bill, information provided by agribusiness companies and extension agents, and a plethora of other matters factor into a farmer's decision-making. ${ }^{390}$ Thus, additional incentives

388. U.S. DEP'T OF AGRIC., USDA AGRICULTURAL PROJECTIONS TO 2022, 2, 8 , 22-35 (Feb. 2013), http://www.ers.usda.gov/media/1013562/oce131.pdf.

389. Edward T. McMahon, The Greening of the Real Estate Industry, URBAN LAND (Jan. 20, 2012), http://urbanland.uli.org/economy-markets-trends/thegreening-of-the-real-estate-industry/.

390. Maria S. Bowman \& David Zilberman, Economic Factors Affecting 
may be necessary to make a LEED-type program desirable.

Incentives to encourage farmers to structure their practices to obtain the proposed certification could come in a number of forms. For example, there are many incentive programs in the Farm Bill that either encourage the growing of certain crops or the use of certain practices. ${ }^{391}$ The proposed whole-system certification program could be folded into one or more of these incentive programs. Farmers who garner sufficient points to obtain specified levels of certification (whether a LEED-type silver, gold, and platinum levels or some other hierarchy) could be eligible to receive payments through one of the existing Farm Bill payment programs, 392 a new Farm Bill program, or an ecosystem services payment program. Another form of encouragement could come through tax relief for farmers who obtain certification. Of course, the greatest incentive may come from the consumers themselves. When informed by the whole-system certification and product labeling proposed in this Article, consumers who value biodiversity, sustainable farming practices, and the establishment of a resilient agricultural system may be willing to shift their purchasing practices to seek out agricultural products that come from farms that have obtained certification and potentially may be willing to pay a premium for such products. The dramatic growth in the organic food market and increasing interest in locally and sustainably grown foods suggest that the whole-system certification may be attractive to certain consumers. The key to having this approach embraced by farmers and consumers may be educating both groups about the potential impacts of climate change on our agricultural system and the ways in which our agricultural system can be made more resilient.

\section{CONCLUSION}

Climate change is one of the greatest global challenges of

Diversified Farming Systems, 18 ECOLOGY \& Soc'Y 33, 34-35 (2013).

391. For a detailed discussion of Farm Bill payment and incentive programs, including income and price support programs, as well as conservation and working lands programs, see generally Mary Jane Angelo \& Joanna Reilly-Brown, An Overview of the Modern Farm Bill, in FOOD, AGRICULTURE, AND ENVIRONMENTAL LAW (Mary Jane Angelo et al. eds., 2013).

392. Id. 
our time. ${ }^{393}$ If we, as a society, seek to develop and ensure global food security, it will become more and more necessary in the coming decades to find ways of transforming our agricultural system to both mitigate the impacts and adapt to the changes as climate change becomes increasingly pronounced. ${ }^{394}$ This means we must develop strategies to eliminate agriculture as a significant source of global GHG emissions (mitigation) and to increase its capacity to absorb climate change-induced effects that have the potential to negatively impact agriculture's ability to thrive (adaptation). Science demonstrates that building an ecologically resilient agro-ecosystem that has high biodiversity and maintains ecosystem functions is key to having an agricultural system that can adapt to the likely changes that will occur as the earth warms. ${ }^{395}$ Based on the successful LEED green building certification program, the whole-system agricultural certification program proposed in this Article seeks to accomplish both goals-mitigation and adaptation-by rewarding biodiversity and ecosystem services-enhancing agricultural practices that contribute to both reducing agriculture's overall GHG emissions and increasing its overall resilience.

393. See Raymond B. Ludwiszewski \& Charles H. Haake, Climate Change: A Heat Wave of New Federal Regulation and Legislation, FED. LAW. 32, 32 (2009) (explaining that global climate change is currently the most significant environmental concern).

394. IPCC SUMMARY FOR POLICYMAKERS, supra note 3, at 19.

395. Richardson, supra note 194 , at 3545 . 